\title{
Ideologia explica tudo? 0 embate no legislativo brasileiro em matérias de política externa ${ }^{1}$
}

\author{
Ideology explains everything? The clash in the \\ brazilian legislative branch on foreign policy matters
}

DOI: $10.21530 /$ ci.v13n2.2018.764

Rodrigo Santiago ${ }^{2}$

\section{Resumo}

De acordo com a literatura especializada, a unidade entre os partidos políticos aumenta a credibilidade da política externa, na medida em que o presidente não fica dependente de ciclos majoritários dentro do parlamento. Essa seria uma estratégia utilizada para afastar o perigo de um oponente estrangeiro explorar as disputas partidárias da arena doméstica em negociações internacionais em situações de crise. No entanto, em algumas circunstâncias, percebe-se momentos de embates que podem ser lidos, majoritariamente, como disputas ideológicas, mas também, a partir da clivagem governo versus oposição e dos interesses federativos dos congressistas. Este trabalho foca nas discussões em plenário e nos pareceres contrários - momentos de conflito - no Congresso Nacional brasileiro entre os anos de 1988 e 2014. Utilizou-se o método da análise de conteúdo e da técnica da análise de correspondência para explicar esse cenário.

Palavras-chave: Política Externa; Legislativo; Ideologia; Governo versus Oposição; Interesses Federativos.

\footnotetext{
Abstract

According to the specialized literature, the unity among the political parties increases the credibility of foreign policy, since the President is not dependent on majority cycles within the Parliament. That would be a strategy used to ward off the danger of a foreign opponent

1 Este artigo é parte integrante da minha tese de doutorado, a qual teve o auxílio da Coordenação de Aperfeiçoamento de Pessoal de Nível Superior (CAPES). Fica registrado, também, os meus agradecimentos aos pareceristas anônimos da Revista Carta Internacional que contribuíram para o aprimoramento deste paper.

2 Doutor em Ciência Política pela Universidade Federal de Pernambuco (UFPE). Contato: rodrigosantiago_18@hotmail.com.

Artigo submetido em 17/02/2018 e aprovado em 25/06/2018.
} 
explore the partisan disputes in the domestic arena in international negotiations in crisis situations. However, in some circumstances, moments of clashes that can be read, mostly, as ideological disputes, but also from the government versus opposition divide and federal interests of congressmans. This work focuses on discussions in the plenary and in the contrary opinions - moments of conflict - the Brazilian National Congress between the years of 1988 and 2014. Used the method of content analysis and correspondence analysis technique to explain this scenario.

Keywords: Foreign Policy; Legislative Branch; Ideology; Government versus Opposition; Federative Interests.

\section{Introdução}

A maneira como os poderes legislativos funcionam é um fenômeno de grande interesse dos politólogos, visto que ela ajuda a entender as democracias representativas. No caso específico das democracias localizadas na América Latina, há uma grande quantidade de estudos empíricos que tentam explicar as consequências e os determinantes do comportamento legislativo na formulação das políticas públicas em geral. Entretanto, ainda são poucos os esforços para se compreender a atuação dos parlamentares latino-americanos em política externa, em particular.

Dos diversos tipos de matérias que tramitam nos parlamentos, especificamente, no brasileiro, as de política externa possuem características que tornam as interpretações sobre a sua formulação e implementação díspares. A diferença fulcral entre a política interna e a internacional está no paradigma clássico (realismo) das relações internacionais em que, para o primeiro caso, há um Estadonação soberano capaz de legislar e garantir a ordem dentro das suas fronteiras, no segundo, temos a ausência de uma entidade supranacional, sendo o sistema internacional anárquico. Logo, a unidade partidária em temas de política externa pode ser percebida como uma estratégia de segurança nacional, importante em tempos de ameaças e incertezas no ambiente externo. A unidade entre os partidos políticos aumenta a credibilidade da política externa, de acordo com a literatura da área, na medida em que o presidente não fica dependente de ciclos majoritários dentro do Legislativo. Além disso, a coesão entre os partidos torna mais difícil um oponente estrangeiro explorar as disputas partidárias da arena doméstica em negociações internacionais em momentos de crise ou conflito. 
Entretanto, para o Congresso Nacional — entre os anos de 1988 e 2014 -, há indícios de embates ideológicos nas discussões em plenário e nos pareceres contrários elaborados. Não está se afirmando que os parlamentares brasileiros sejam altamente combativos nesse tipo de matéria, mas que há alguns temas e momentos que chamam mais a atenção de tais parlamentares e da sociedade, fazendo com que haja uma maior participação dos mesmos. Por meio do método da análise de conteúdo e da técnica da análise de correspondência, busca-se encontrar indícios que corroborem ou não esse quadro. Além dessa introdução, o artigo é composto de mais quatro seções: (1) uma visão geral sobre o papel dos partidos políticos e suas ideologias; (2) o debate acerca da ideologia partidária no Brasil; (3) uma discussão sobre o papel da ideologia, da clivagem governo versus oposição e interesses federativos na análise de política externa; (4) uma parte empírica em que são mostrados os achados da pesquisa; e, por fim, estão as considerações finais.

\section{Partidos e ideologias: uma visão geral}

O conceito direita-esquerda é histórico, ele remonta à Revolução Francesa, na reunião dos Estados Gerais, no século XVIII. Aqueles identificados com ideias igualitárias e reformas sociais sentavam-se à esquerda do monarca; por outro lado, os que tinham vínculos com a aristocracia e defendiam ideias conservadoras estavam à direita dele. Já no século XIX, no continente europeu, a diferenciação entre direita e esquerda passa a ser vista como sinônimo para conservadorismo e liberalismo, respectivamente (TAROUCO; MADEIRA, 2013).

Com o desenvolvimento do movimento operário e a expansão do pensamento de Karl Marx, o conteúdo proposto pela esquerda passou a incluir a defesa dos interesses da classe operária. Com as discussões sobre a social-democracia, no final do século XIX, e a Revolução Russa, de 1917, a defesa do capitalismo põe a burguesia na direita (PRZEWORSKI, 1988). Por último, o surgimento do keynesianismo, na década de 1930, e dos Estados de bem-estar social, com políticas de cunho redistributivo, reacendem a dicotomia entre o livre-mercado e o Estado provedor, colocando, também, o liberalismo para a direita (TAROUCO; MADEIRA, 2013). Apesar das mutações de significado que os termos direita e esquerda tomaram nos últimos dois séculos, a afinidade da defesa da igualdade social, herdeira dos princípios socialistas, com a esquerda e da defesa do livre-comércio capitalista 
com a direita parece ser uma questão viva e contemporânea. Gabriela Tarouco e Rafael Madeira pontuam que:

O debate acerca da pertinência do uso contemporâneo das classificações ideológicas é bem familiar a quem estuda partidos políticos. Trata-se de saber se as categorias esquerda e direita ainda ajudam a explicar a política no mundo pós-guerra fria. Além disso, em países nos quais o welfare state atendeu minimamente as disputas distributivas, emergem as chamadas questões pós-materialistas, que não correspondem à dimensão Estado-mercado. Ao mesmo tempo, a direita ressurge em vários países europeus com vitórias eleitorais sobre os tradicionais partidos social-democratas, sugerindo que a diferenciação ainda faz algum sentido (TAROUCO; MADEIRA, 2013, p. 149).

Desse modo, as diferenças ideológicas continuam sendo usadas como variável explicativa para analisar desde a lógica das coligações partidárias até as políticas públicas executadas pelos governos. Da mesma forma que a diferenciação ideológica permanece como elemento para classificar as percepções dos eleitores e o seu nível de identificação política.

A identificação de perfis partidários, no debate atual da ciência política, pela sua localização unidimensional tem origem em Anthony Downs (1999). Segundo o autor, as agremiações partidárias se movem ao longo de um continuum ideológico formulando propostas de políticas com o objetivo de obter votos. Essa perspectiva pressupõe que os atores políticos em contextos democráticos se orientam de maneira racional, de forma similar a agentes econômicos no mercado. Assim, para alcançar os seus objetivos, partidos procuram maximizar votos e se eleger; governos, maximizar apoio político e se reeleger; e os eleitores, escolher um governo em que as políticas ampliem seus benefícios. Dessa maneira, os partidos formulariam políticas no intuito de ganhar eleições e não o inverso, isto é, não disputam eleições com a meta de implementar políticas (DOWNS, 1999).

Os partidos têm a possibilidade restrita de encaminhar seu apelo eleitoral a um número pequeno de grupos sociais, por isso, cada agremiação formularia sua ideologia de maneira a agradar aquele conjunto específico de grupos. Eles usariam o desenvolvimento de ideologias como um método para angariar votos e ficariam obrigados a alguma honestidade e coerência na consecução de políticas ao longo do tempo. No entanto, cada partido quer agradar a tantos eleitores quanto possível. A consequência lógica disso é que, no final das contas, nenhum partido se prende a uma ideologia de modo rígido demais. A limitação a uma ideologia perante novas situações seria uma ação irracional (DOWNS, 1999). 
Para Downs (1999), a posição de cada grupo partidário variaria a partir da expectativa de preferência do eleitor mediano, cujo voto os partidos desejam. Assim, eles se movem racionalmente na escala direita-esquerda para ganhar votos. Como outra via possível de interpretação das escolhas ideológicas dos partidos surge a saliency theory, desenvolvida por David Robertson (1976). Para ele, os partidos competem fazendo uso da proeminência de diferentes temas, mais do que pela tomada de várias posições a respeito das mesmas questões.

A partir disso, neste artigo, a noção de identidade partidária será operacionalizada por meio das preferências expressas na atividade parlamentar naqueles temas que geraram algum tipo de intervenção na tramitação dos atos internacionais. Esse enfoque está baseado na teoria das ênfases programáticas de maneira adaptada, pois, não se analisa nem os programas de governo (BUDGE et al., 2001; KLINGEMANN; HOFFERBERT; BUDGE, 1994), nem os manifestos dos partidos políticos (LAVER; BUDGE, 1992; KLINGEMANN et al., 2006; TAROUCO, 2007), mas sim os pronunciamentos dos parlamentares em plenário, as emendas e os pareceres elaborados por eles. Com isso, pretende-se verificar se os partidos se diferenciam pelas ênfases que dão às várias questões que se colocam.

Visões distintas apresentadas, nesta seção, mostraram que os partidos políticos podem se manifestar como agremiações utilitárias - como a defendida por Downs (1999) - ou como defensores de visões de mundo - de acordo com Robertson (1976). Este paper não pretende excluir nenhuma das explicações, pois acreditase que elas são complementares, apesar de bem diferentes. Diante desse quadro, assume-se que os partidos importam. Entretanto, é necessário precisar como eles se tornam relevantes para o debate e para o artigo, em particular. A seguir, situaremos o Brasil na discussão proposta, mostrando suas especificidades diante do contexto apresentado nas democracias europeias, por exemplo.

\section{Ideologia e partidos políticos no brasil}

No Quadro 1, vê-se os temas que caracterizariam posicionamentos típicos de partidos de direita e de esquerda extraídos dos estudos que focam nesse contínuo de preferências políticas. E que servirá como categorias analíticas na seção empírica. 
Quadro 1. Os temas que seriam típicos na comparação direita-esquerda

\begin{tabular}{|c|c|}
\hline Direita & Esquerda \\
\hline Forças Armadas: positivo & Anti-Imperialismo \\
Liberdade & Direitos Humanos \\
Constitucionalismo: positivo & Paz \\
Autoridade Política & Internacionalismo: positivo \\
Livre-iniciativa & Democracia \\
Incentivos & Regulação do Mercado \\
Protecionismo: negativo & Protecionismo: positivo \\
Ortodoxia Econômica & Economia Controlada \\
Limitação de Gastos & Nacionalização \\
Nacionalismo: positivo & Expansão de Gastos \\
Lei e Ordem & Classe Trabalhadora: positivo \\
\hline
\end{tabular}

Fonte: adaptado de Klingemann et al., 2006 e Tarouco; Madeira, 2013.

Nessa perspectiva, saber como os congressistas se posicionam em um ou mais temas do Quadro 1 pode ajudar a categorizá-los e, consequentemente, ao seu partido como sendo de direita ou de esquerda. É preciso, porém, estar atento para uma correção realizada por Tarouco e Madeira, e adotada por esta pesquisa:

A escala definida pelo Manifestos Research Group (MRG) [...], por exemplo, inclui, entre os elementos constitutivos da posição política de esquerda, a defesa do internacionalismo e a busca da paz entre países, e, entre elementos constitutivos da posição política de direita, entre outras coisas, a defesa do constitucionalismo e de liberdades e direitos humanos. Tais critérios fazem pouco sentido na política de países ex-colônias, que não passaram pelos mesmos processos históricos revolucionários que moldaram as visões de política nos países europeus (TAROUCO; MADEIRA, 2013, p. 157).

De acordo com André Singer (2002), no Brasil, não é o tema da igualdade que diferencia a esquerda da direita, como em outros países. Aqui, o que provoca a clivagem são os meios empregados para alcançá-la. A direita tenderia a reforçar a autoridade do Estado, no intuito de que a busca da igualdade não implique em perda da ordem. Por outro lado, a esquerda criticaria tal autoridade, principalmente quando ela reprime os movimentos sociais/igualitários. Nesse sentido, o espectro direita-esquerda tem que considerar as contradições inerentes ao papel do Estado na sociedade. 
Ainda sobre esse aspecto, Tarouco e Madeira (2013) explicam que a escala apresentada pelo Manifesto Research Group (MRG) inclui categorias que não fazem sentido na realidade brasileira. Por exemplo, por conta da experiência ditatorial, iniciada na década de 1960, e da transição democrática dos anos de 1980, a esquerda brasileira incorpora bandeiras que o MRG identifica como sendo de direita: liberdade, direitos humanos e constitucionalismo. Pela mesma razão, a defesa da democracia, que é apontada como comum à esquerda, no Brasil, aparece no discurso de todos os partidos que surgiram no período da reabertura política, o que não impede, por parte da direita, a defesa das Forças Armadas.

Alguns pesquisadores utilizam os resultados das votações em plenário para concluir sobre a posição ideológica das bancadas dos partidos políticos. Entretanto, esquecem que essa relação não pode ser direta. Não se pode excluir dessas decisões o caráter estratégico da sobrevivência política ou a relação entre coalizão governista e oposição (MADEIRA; TAROUCO, 2011).

Em pesquisa comparativa, André Marenco e Miguel Serna entendem que o eixo direita-esquerda é uma relevante dimensão na organização do regime e dos partidos políticos dos três sistemas multipartidários analisados (Brasil, Chile e Uruguai). Os autores consideram que, de fato, existem partidos de esquerda e de direita e com representação nos sistemas partidários escolhidos. Mas, sobre as dificuldades de conceituar tal clivagem entre as agremiações, eles enfatizam que:

As decisões que dizem respeito à delimitação da esquerda e da direita não estão isentas de dificuldades. Desde sua definição originária na Europa, passando por múltiplas transformações históricas posteriores - principalmente depois de 1989 —, os termos "esquerda” e "direita” têm significado polissêmico, apresentando pelo menos duas dimensões diferentes, muitas vezes superpostas em seu sentido histórico. A primeira é espacial-situacional, uma vez que a polarização esquerda-direita definiu em forma dicotômica as posições relativas de cada ator dentro de um sistema político historicamente determinado - com clivagens sociais e políticas diversas. A segunda é de ordem ideológica, que concerne aos valores e às crenças de doutrinas políticas, podendo ser dividida entre correntes favoráveis ao igualitarismo e à mudança social (por exemplo, socialistas, comunistas, social-democratas etc.) e os partidários da liberdade individual e da ordem social (como liberais, conservadores, entre outros) (MARENCO; SERNA, 2007, p. 94-95).

Apesar das dificuldades apontadas pelos trabalhos que tratam da ideologia como elemento explicativo para a execução de políticas, todos enfatizam a 
importância de tal variável. Desse debate, formula-se o objetivo e a hipótese de trabalho. A meta é analisar a atuação parlamentar, focando na clivagem governo versus oposição, partidos políticos (ideologia) e interesses federativos das bases eleitorais e seus impactos na tramitação dos atos internacionais. Nesse sentido, tem-se como hipótese que: a ideologia de fato divide os partidos políticos em clusters, mas é preciso estar atento à relação governo x oposição e aos interesses federativos para poder explicar a tramitação dos atos internacionais.

\section{Análise de política externa e ideologia política: entre a clivagem governo versus oposição e os interesses federativos}

Nos subitens a seguir, será feito um levantamento de como as três variáveis de interesse do estudo - ideologia política, clivagem governo x oposição e interesses federativos - podem interferir na dinâmica legislativa em política externa. Pesquisas têm mostrado o elevado peso da orientação partidária no comportamento legislativo em política externa. Os resultados também mostraram que o federalismo, em algumas circunstâncias e para certos casos, complementa a explicação. Esses achados aproximam a dinâmica legislativa em política externa da dinâmica da política doméstica. Durante algum tempo, os autores brasileiros estiveram presos ao argumento da omissão ou abdicação dos parlamentares frente ao Executivo - no tocante à política externa ${ }^{3}$. Entretanto, estudos iniciados no final dos anos 2000 mostraram que, se o intuito era entender e explicar a atuação congressual na dimensão dos atos internacionais, se fazia necessário incorporar novos conceitos e teorias que fossem além da área das relações internacionais. Diante desse quadro, surgem teorias que ora focam no ator político como um maximizador das suas chances de reeleição e ora dão ênfase aos conteúdos programáticos a partir da proeminência de alguns temas. A verdade é que as análises podem ser frutíferas caso aliadas, desde a perspectiva ideológica até a pragmática das coalizões governistas e dos interesses federativos.

\section{Ideologia partidária e clivagem governo versus oposição}

A ideologia dos partidos políticos é uma variável explicativa para o comportamento dos legisladores em grande parte dos estudos que focam nas

3 Para detalhes sobre o assunto, ler Rodrigo Santiago (2016). 
políticas públicas em geral (FIGUEIREDO; LIMONGI, 1999, 2007; POOLE; ROSENTHAL, 1997; LEONI, 2000). O argumento central dessas pesquisas é que existe uma correlação entre a posição dos partidos políticos dentro do espectro ideológico direita-esquerda e o voto dos congressistas. Um elemento fundamental que sustenta esse raciocínio é a coesão partidária, ou seja, a identificação de uma clara influência das escolhas dos partidos políticos no voto individual dos parlamentares (HAGER; TALBERT, 2000).

Pesquisa realizada por Jean-Philipe Thérien e Alain Noel (2000) exemplifica bem como os partidos políticos podem influenciar na tomada de decisão governamental. Ao comparar 16 países membros da OCDE (Organização para a Cooperação e Desenvolvimento Econômico), o estudo tentou entender se parlamentos formados por partidos de diversos matizes (socialistas, socialdemocratas, liberais, religiosos, dentre outros) têm maior afinidade a empenhar uma boa parcela do PIB nacional em ajudas humanitárias externas. Com base nesse problema, os autores concluíram que os Estados em que os governos são formados por partidos de origem social-democrata investem mais em ajuda externa do que os governos liberais. Claramente, a ideologia partidária seria uma proxy para explicar as políticas públicas domésticas, mas também, a política internacional.

Nessa mesma linha de raciocínio, Gary Marks et al. (2006) investigam a competição partidária no processo de integração regional europeu. Os pesquisadores localizam os partidos nas duas dimensões clássicas do espectro ideológico (direitaesquerda) e as dimensões (liberalismo-ambientalismo) versus (tradicionalismonacionalismo). Como achado principal, encontram relação entre o posicionamento dos partidos quanto a apoiar a integração regional nos seis aspectos citados. Além disso, notaram que as associações se invertem a depender se os partidos são do Leste ou Oeste da Europa.

Por outro lado, os trabalhos sobre política comercial que analisam a atuação dos grupos de pressão indicam que é irrelevante a ideologia partidária com relação à temática (RAY, 1981). O argumento é: se a política comercial é consequência das preferências e influências dos grupos de interesses, a ideologia dos partidos políticos é pouco importante, pois cada partido tende a representar vários grupos sociais com diferentes preferências. Na mesma linha, Gene Grossman e Elhanan Helpman (1994) afirmam que setores econômicos organizados em lobbies dominam a política comercial, fazendo com que os partidos tenham diminuta relevância. Pesquisas mais recentes examinaram o posicionamento dos partidos políticos sobre tais questões em 25 países desenvolvidos, grande parte deles membros da OCDE, 
no período compreendido entre 1945 e 1998. O principal achado foi a existência de um forte impacto dos partidos políticos, principalmente, no que tange à lógica direita-esquerda (MILNER; JUDKINS, 2004).

Na América do Sul, Pedro Feliú Ribeiro, Manoel Pereira Neto e Amâncio Oliveira (2007) encontraram que a ideologia partidária, no caso do Chile, tem o poder preditivo para a formação das preferências dos deputados em temas de política comercial, mesmo se controlada por interesses locais. Outros achados de Pedro Feliú Ribeiro (2012) são que, na comparação entre os seis países do estudo (Argentina, Brasil, Chile, México, Paraguai e Peru), existe uma baixa diferenciação do comportamento legislativo em assuntos internos e externos. E a disposição ideológica dos partidos políticos relaciona-se com o binômio governo-oposição enquanto elementos explicativos dos votos dos parlamentares da região, independentemente da temática. Ele ressalta que algo parecido ao bipartisanship ${ }^{4}$ norte-americano parece não fazer sentido nos casos selecionados. Ribeiro (2012) argumenta que os partidos políticos têm posições diferentes a respeito da implementação e execução da política externa. Portanto, a formação das preferências internacionais não pode ser entendida como suprapartidária. Comparativamente ao termo bipartisanship baseado na experiência estadunidense, o autor afirma que nos países latino-americanos não há a ocorrência de um multipartisanship, ou seja, legislaturas multipartidárias em que maiorias partidárias votam fechado nas políticas de cunho internacional.

Por outro ângulo de análise, Simon Hix e Abdul Noury (2011) enfatizam que a primeira característica a ser levada em consideração para a análise dos votos dos parlamentares em distintos contextos institucionais é a batalha entre os legisladores pertencentes ao governo ou à oposição, independentemente da opção (preferência) política em si. Os integrantes da oposição tendem a se colocar de maneira contrária ao governo, muito mais para sinalizar a sua postura de oposição do que para demonstrar descontentamento com alguma proposta legislativa em particular.

Na maioria dos países latino-americanos, o presidente tem forte controle sobre a distribuição de recursos e cargos e, por isso, sobre a agenda política,

4 No caso dos Estados Unidos é caracterizado por: 1) Unidade em assuntos externos, ou seja, apoio político dos dois principais partidos do país; e 2) Práticas e procedimentos tomados com o objetivo de atingir a almejada unidade. Dessa forma, o grau de polarização entre os democratas e republicanos se mostraria diferente quando comparada as votações de questões domésticas e internacionais, estando o primeiro caso sujeito às forças centrífugas da polarização, e o segundo, guiado pelas forças centrípetas do bipartisanship (MCCORMICK; WITTKOPF, 1990; KEGLEY; WITTKOPF, 1995). 
sendo capaz de atrair o apoio dos congressistas ao redor das suas propostas legislativas. Hix e Noury (2011) enfatizam que a dimensão governo-oposição, em muitos casos, pode estar ligada à divisão ideológica do tipo direita-esquerda. No caso do sistema latino-americano, é comum os estudos argumentarem sobre a relevância do continuum direita-esquerda enquanto organizador da política, facilitando a transmissão de informação aos eleitores no momento da competição política. Desse modo, a ideologia dos partidos políticos também está presente enquanto variável explicativa para entender a participação parlamentar no debate sobre política externa.

Esse debate não é consensual, por exemplo, para César Zucco Jr. (2009), esquerda e direita ainda tem a ver com maior ou menor intervenção do Estado na economia, entretanto, houve uma considerável retração dos posicionamentos mais à esquerda. Na verdade, o autor levanta a tese de que a ideologia jamais tenha sido uma proxy forte de comportamento. Segundo ele, a questão continua em aberto por problemas de ordem empírica para os anos dos mandatos do ex-presidente Lula, quando as coalizões de governo foram ideologicamente incoerentes, podendo assim se distinguir ideologia de pragmatismo político. No caso da $53^{\text {a }}$ legislatura estudada, Zucco Jr. (2009) afirma que a principal clivagem é mesmo entre oposição e governo, e não direita e esquerda. Esse achado corrobora a ideia de que, quando há disputas entre as preferências ideológicas dos congressistas, os incentivos gerados pelo Executivo tendem a ser preponderantes.

Criticamente, Tarouco e Madeira (2015) apontam que um certo grupo de pesquisadores enfatizam a alta fragmentação do sistema partidário brasileiro, a heterogeneidade das coligações e o personalismo na escolha eleitoral como alguns dos fatores que indicam que os partidos políticos no país não possuem ideologia definida. Entretanto, ironicamente, existe uma grande quantidade de classificações na literatura da ciência política (KINZO, 1993; MELO, 1999; MAINWARING, MENEGUELLO e POWER, 2000; AMORIN NETO, 2000; MARENCO, 2001; RODRIGUES, 2002; ZUCCO JR., 2009; 2011) que distinguem as agremiações em direita, centro ou esquerda. Os trabalhos que enfatizam essa volatilidade ou inconsistência ideológica baseiam suas conclusões no comportamento dos parlamentares nas votações nominais em plenário. Porém, como salienta Peter Mair (2001), ideologia não se confunde com posições defendidas em relação a políticas específicas, logo, resultados pautados em votações nominais podem ser apenas preferências - de sobrevivência política - imediatas e não ideológicas. 
Desse mesmo ponto de vista, Eduardo Leoni (2002) afirma que não é difícil ver políticos, jornalistas, acadêmicos e cidadãos usarem conceitos espaciais para identificar as posições dos atores políticos. A teoria espacial dos votos é uma tentativa de sistematização desse pensamento. Ela tem como fundamento a ideia de que as preferências individuais e as políticas podem ser indicadas como pontos em um espaço. A lógica é que os atores dão mais valor/preferem as políticas mais próximas, em detrimento daquelas que se encontram mais distantes dos seus pontos ideais. Para o caso norte-americano, podemos dizer que:

Um liberal dos dias de hoje [...] provavelmente apóia um aumento no salário mínimo; [...] é contra o uso de força no estrangeiro; apóia programas compulsórios de ação afirmativa; e apóia o financiamento federal de programas seguro-saúde e creches. De fato, saber se um político se opõe a um aumento do salário mínimo é suficiente para predizer, com razoável confiabilidade, a opinião do político em muitas questões aparentemente desconexas (POOLE; ROSENTHAL, 1997, p. 11 apud LEONI, 2002, p. 372).

O entendimento da política externa enquanto matéria sujeita a disputas político-ideológicas evidencia a importância da inclusão das preferências partidárias nas pesquisas sobre formulação da política externa na América Latina (OLIVEIRA; ONUKI, 2010). Dada a relevância das variáveis ideologia do partido político e pertencimento à coalizão de governo, pode-se concluir que, a depender da configuração partidária, presidentes podem ter dificuldade para levar a cabo suas agendas internacionais. Em ambientes de governo dividido e alta polarização ideológica, é esperado que os legislativos sul-americanos ajam como importantes veto players da política externa presidencial. Nesse sentido, parece sensato supor a antecipação, por parte do presidente, das preferências do legislador mediano na formulação da política externa. Por isso, neste trabalho, utiliza-se a ideologia e a clivagem governo versus oposição como complementares e não como visões antagônicas.

\section{Interesses federativos}

Há ainda um terceiro elemento que se junta à ideologia partidária e à clivagem governo x oposição: são os interesses federativos. Cheryl Schonhardt-Bailey (2006) procurou compreender a razão de uma parcela do Partido Conservador britânico 
ter optado por desafiar o partido e gerar, em 1846, a remoção da legislação que protegia os produtores de trigo. Ainda mais que grande parte do apoio partidário era oriundo exatamente dos agricultores sensíveis, portanto, à livre-concorrência de importados. Estudando as bases distritais dos parlamentares dissidentes, a autora concluiu que a gênese da alteração de posição está ligada a uma mudança nas próprias constituencys. Além dos bens agrícolas, os distritos passaram a produzir bens manufaturados. Essa mudança na cadeia econômica promoveu uma heterogeneização na base de suporte do Partido Conservador, que também passou a lutar pela abertura econômica e pela internacionalização. Logo, os interesses econômicos da base eleitoral de uma parcela do partido teriam prevalecido sobre a sua ideologia primária. Em outras palavras, os fatores determinantes da indisciplina partidária seriam de ordem local, bem como econômica (os lobbies), elementos que passaram a ser mais importantes para a sobrevivência dos parlamentares envolvidos do que a ideologia partidária.

Os acadêmicos que relacionam o federalismo à política externa afirmam que os parlamentares de diferentes regiões possuem interesses distintos não só em questões internas, mas também em temas internacionais. Assim, cada ente federativo teria suas particularidades a partir dos seus vínculos com o exterior. Porém, há os que afirmam que, independentemente dos interesses locais, os congressistas seguiriam fiéis aos seus princípios político-partidários. Oliveira chama atenção para o seguinte:

As especificidades sub-regionais podem ser, do ponto de vista substantivo, determinadas por qualquer arena das relações internacionais, tais como comércio, defesa, segurança, meio-ambiente e assim sucessivamente. A título de exemplo, os estados podem ter interesses distintos na área tributária, a depender se são estados exportadores ou não, em uma legislação como a Lei Kandir sobre isenção de impostos para os exportadores. No campo da segurança sub-regional, as realidades dos estados amazônicos e do CentroOeste tendem a ser distintas das dos demais por conta de questões de fronteira (migração, tráfico de ilícitos, segurança pública e etc). No campo do comércio internacional pode-se dizer que os estados do norte do país tendem a ter vínculos comerciais distintos das demais unidades da federação com os países da região andina, por razões locacionais e logísticas. Do mesmo modo, os estados do Sul podem manter vínculos comerciais mais intensos com os países do cone sul, pelas mesmas razões supra-citadas. Além das questões locacionais e logísticas, os estados diferenciam-se em relação a suas matrizes produtivas o que reforçaria comportamentos diferenciados dos seus legisladores (OLIVEIRA, 2013, p. 36). 
Das várias contribuições do trabalho de Amâncio Oliveira (2013), duas merecem destaque. A primeira é o fato de ter mostrado o elevado peso da orientação partidária no comportamento legislativo em política externa. E, segunda, os resultados também mostraram que o federalismo, em algumas circunstâncias e para certos casos, complementa a explicação baseada na disciplina partidária. Esses achados aproximam a dinâmica legislativa em política externa da política doméstica, como também incorpora novos conceitos e teorias para além da área das relações internacionais para ajudar a entendê-la.

\section{Dados qualitativos}

O método da análise de conteúdo consiste no tratamento quantitativo para dados qualitativos. A partir da classificação de uma quantidade considerável de unidades textuais (palavras, expressões, frases), compartimentamo-las em categorias de acordo com o seu significado (BARDIN, 2006). Posteriormente, as relações são quantificadas, e, a partir disso, são produzidas inferências válidas para o texto inicial. A ideia é que a medida da presença de uma determinada categoria espelhe a relevância conferida a ela no texto em geral. A seguir, é explicada a amostra e as categorias analíticas, como também, discute-se preliminarmente os resultados das análises de correspondência.

\section{Corpus da pesquisa, categorias e análise descritiva dos dados}

A pesquisa contou com a utilização do software QDA Miner versão 4.1.23 para a elaboração do corpus da pesquisa. Esse corpus contém 112 discursos que foram extraídos da matriz construída no SPSS para a Câmara dos Deputados e para o Senado Federal durante os anos de 1988 e 2014. Foram analisados os textos produzidos pelos parlamentares nos momentos em que eles atuaram durante a tramitação dos atos internacionais dentro do universo amostral. Desse total de 112 discursos, emendas, pareceres contrários, 81 (72,3\%) foram proferidos por deputados federais e $31(27,7 \%)$ por senadores. O objetivo dessa análise é entender a razão das intervenções, os pontos de vista e as diferenças ideológicas que possam surgir, também, no debate da política externa. 
Com isso, não se está falando sobre um ativismo parlamentar na matéria, mas se quer explicar por que houve divergências entre os membros do Congresso Nacional brasileiro. O intuito dessa subseção da pesquisa é averiguar o impacto da variável ideologia, como também o impacto da dicotomia governo versus oposição e dos interesses federativos. Não à toa, foi realizada uma discussão teórica prévia sobre esses elementos. Com o auxílio da saliency theory, elaborou-se um quadro com os domínios que foram utilizados para a análise dos textos coletados. Assim, tem-se 8 domínios que são: 1) Relações Exteriores ${ }^{5}$; 2) Liberdade e Democracia; 3) Sistema Político; 4) Economia; 5) Bem-Estar e Qualidade de Vida; 6) Estrutura da Sociedade; 7) Questão Indígena e Segurança Amazônica; e 8) Tramitação dos Atos Internacionais e Fiscalização do Congresso.

Vários partidos, durante os 26 anos que a pesquisa cobre, se posicionaram sobre os temas da política externa, nos discursos em plenário, através de emendas e pareceres contrários. Entretanto, vale o destaque para os considerados pela literatura especializada como os quatro grandes partidos e que mais participaram dos debates: PT (25\%), PSDB (17\%), PMDB (11,6\%) e PFL-DEM (11,6\%). Além disso, essa participação de 65,2\% dos partidos supracitados pode ser explicada pelo fato de eles terem feito parte diretamente dos governos eleitos para o Executivo federal no período que abrange a análise e, como já discutido, a variável governo x oposição é fundamental para que os membros das bancadas no parlamento se posicionem a favor ou contrários às políticas.

Esse também é o momento para esclarecer alguns aspectos metodológicos. Na mesma amostra (112 casos), que pode ser vista no Gráfico 1 em porcentagens: 1) há casos de missing (sem informação - 5,4\%), isto é, se teve acesso ao material textual, mas não foi possível identificar o seu autor e, portanto, o partido/ideologia do deputado/senador; e 2) há o material dos parlamentares “sem partido”, que são três — os deputados Fernando Gabeira ${ }^{6}$, Babá7 e Luciana Genro ${ }^{8}$.

5 Essa dimensão subdivide-se em: 1) imagem do país no cenário internacional; 2) integração latino-americana; 3) Estados Unidos; 4) Paraguai; 5) África; 6) Cuba; e 7) Oriente Médio.

6 Que em discordância com o governo Lula, pede a sua saída do PT em outubro de 2003, e fica temporariamente sem partido.

7 Que foi expulso do PT em 2003 e é um dos fundadores do PSOL.

8 Também expulsa do PT em 2003 e, também, uma das fundadoras do PSOL. 


\section{Gráfico 1. Porcentagem dos partidos que se manifestaram na discussão na Câmara dos Deputados e no Senado Federal}

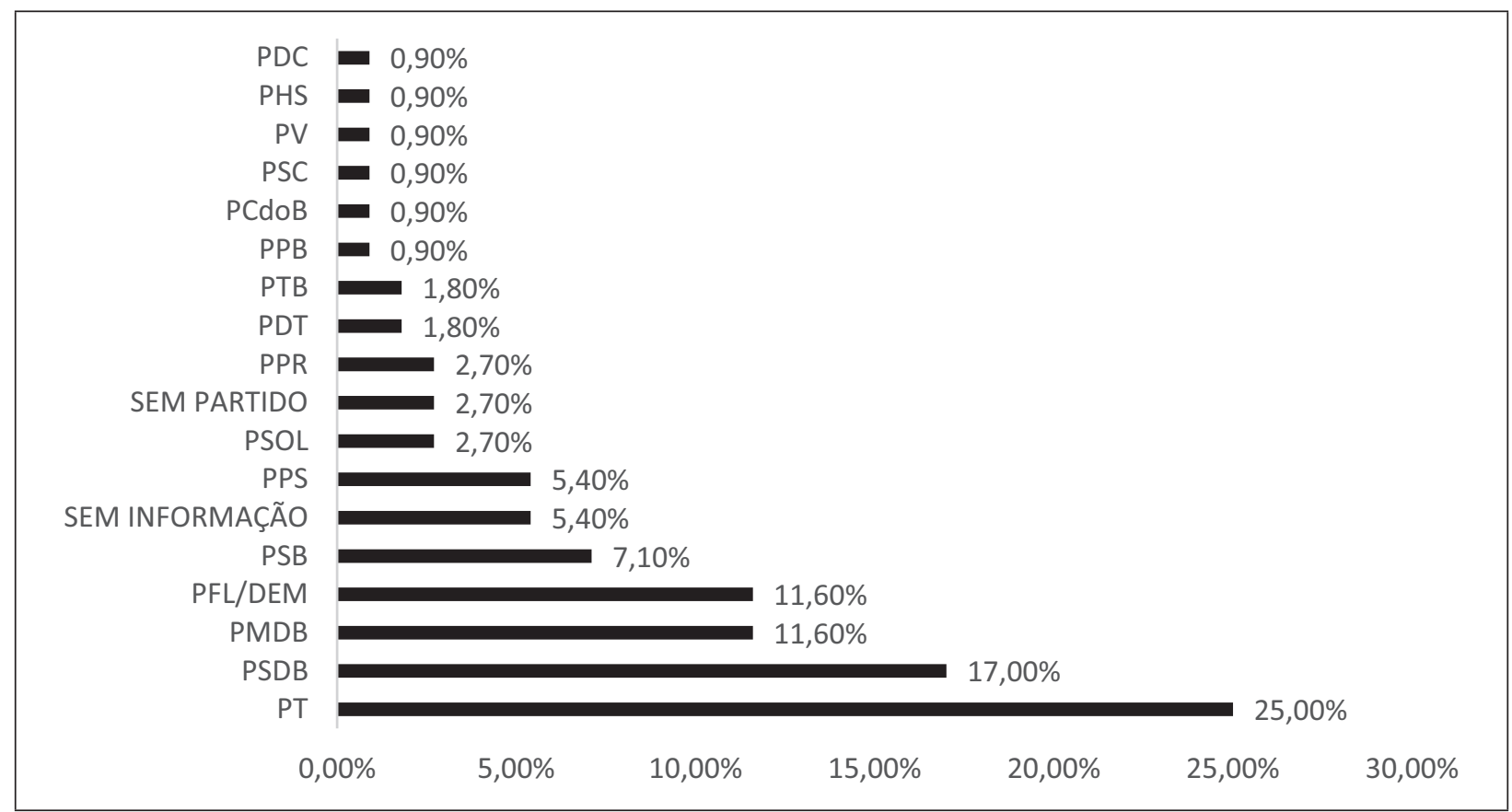

Fonte: banco de dados próprio a partir dos discursos e pareceres dos congressistas, elaborado em 2015.

Outra nota metodológica diz respeito à categorização dos partidos quanto ao seu pertencimento ideológico. Sabe-se das críticas em alocar as agremiações partidárias dentro do espectro ideológico, entretanto, seguindo Yan Carreirão, classifica-se os partidos da seguinte maneira:

Com base [...] nas classificações formuladas nos estudos de Kinzo (1990), Novaes (1994), Figueiredo e Limongi (1999), Fernandes (1995) e Rodrigues (2002), tomo como definição operacional inicial a seguinte classificação dos partidos no Brasil, no eixo direita-esquerda:

Direita: PP (PPB; PPR; PDS); PFL; PRN; PDC; PL; PTB; PSC; PSP; PRP; PSL; PSD e PRONA. Centro: PMDB e PSDB. Esquerda: PT; PDT; PPS; PCdoB; PSB; PV; PSTU; PCO e PMN (CARREIRÃO, 2006, p. 143).

Porém, como visto no Gráfico 1, algumas legendas aparecem no banco de dados, mas não na classificação de Carreirão (2006), são elas: o DEM - sucessor do PFL e, por isso, o classificamos como de direita; o PSOL e o PHS, a respeito dos quais usamos na classificação as suas próprias autodefinições encontradas nos seus sites institucionais - assim, o PSOL está no grupo da esquerda, e o PHS no de centro. No Gráfico 2, vê-se a porcentagem dos textos já classificados a partir do espectro ideológico dos parlamentares. Excetuando os casos em que não tivemos orientação 
sobre o seu autor (6), quase metade dos textos são de partidos de esquerda (46,2\%), seguidos do centro $(31,2 \%)$, direita $(19,8 \%)$ e os sem partido $(2,8 \%)$.

\section{Gráfico 2. Porcentagem de textos caracterizados pelo espectro ideológico dos parlamentares}

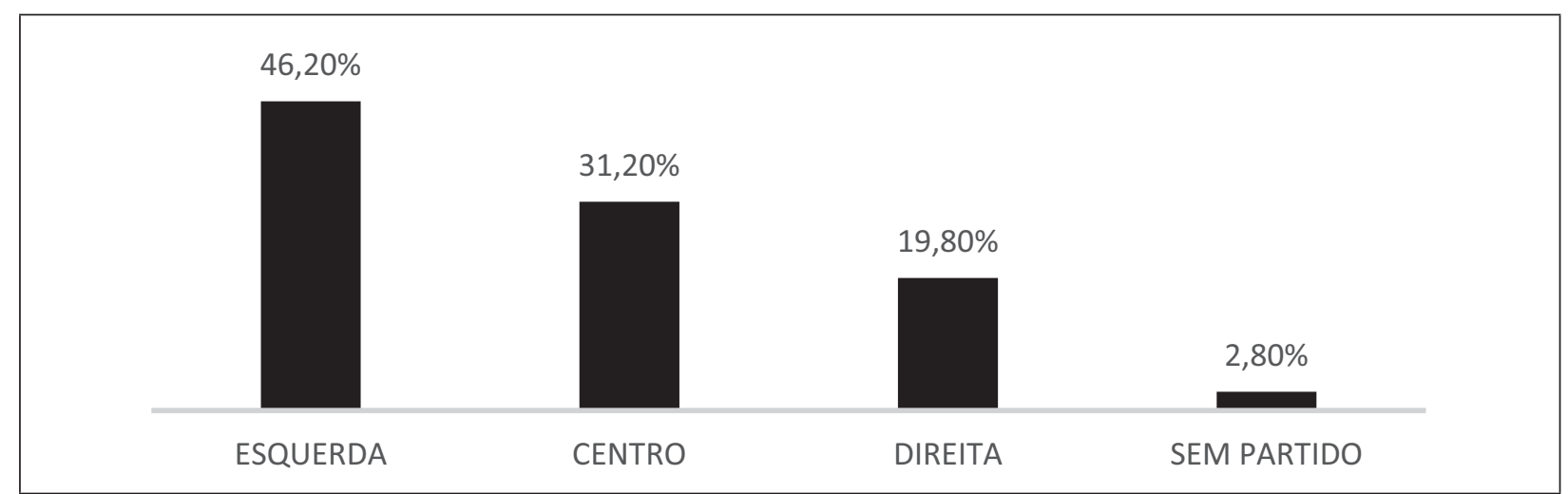

Fonte: banco de dados próprio a partir dos discursos e pareceres dos congressistas, elaborado em 2015.

\section{Análise de correspondência: achados}

Nesta seção, tem-se como propósito básico analisar a atuação parlamentar focando na ideologia, no governo versus oposição e nos interesses federativos das bases eleitorais. Discute-se os resultados das análises de correspondência9 executadas a partir dos domínios definidos pela saliency theory e sua relação com a ideologia dos partidos políticos. Espera-se que as agremiações localizadas em posições dististas no continuum esquerda-direita possuam, também, posicionamentos diferentes quanto aos temas abordados no seus discursos. Isto é, que privilegiem algumas questões/pontos de vista em detrimento de outros.

Para ler os gráficos a seguir, o leitor deverá prestar atenção, inicialmente, nas categorias: direita, centro, esquerda e sem partido. Após isso, o leitor pode identificar em qual quadrante os assuntos se localizam. E, posteriormente, a proximidade dos assuntos tratados com as categorias. Categorias e temas em um mesmo quadrante indicam que o tema faz parte do discurso das categorias verificadas. O objetivo da análise de correspondência é medir o grau de associacão de variáveis dispostas de

9 Segundo Luiz Augusto Campos (2014, p. 389), “A Análise de Correspondências Simples (ACS) é um recurso para expor em um mapa bidimensional as coocorrências relativas entre as classes de duas variáveis categóricas. A partir de uma tabela de contingência simples, em que duas variáveis são cruzadas, a ACS produz uma ilustração cartográfica das relações existentes entre todas as categorias incluídas. As categorias que mais coocorrem em termos relativos tendem a ser representadas mais próximas e, analogamente, as categorias com menor grau de coocorrência são representadas com uma distância maior entre si. Para definir a magnitude dessas distâncias relativas, a ACS considera as distâncias existentes entre os marginais observados na métrica do qui-quadrado”. 
modo gráfico. Assim, quanto mais um tema estiver próximo dos pontos relativos à esqueda, centro, direita ou sem partido, mais eles estarão relacionados.

O Gráfico 3 demonstra o resultado da análise de correspondência para o domínio das relações exteriores, especialmente no tocante à imagem do país internacionalmente. $\mathrm{O}$ embate nesse tema girou em torno do envio de tropas brasileiras para uma missão de paz no Haiti. Os parlamentares da direita, centro e sem partido eram contrários ao envio, por isso, estão mais próximos dos temas ligados às Forças Armadas, ao Conselho de Segurança da ONU (CSNU) e às menções negativas sobre a missão de paz. Por outro lado, os partidos de esquerda, encabeçados pelo governo, eram a favor do envio e argumentavam que participar da missão de paz (menção positiva) possibilitaria ganhar capital político e maior liderança internacional frente à ONU. Além disso, os parlamentares de esquerda são mais propensos a focarem suas posições contra a subserviência brasileira frente aos interesses estrangeiros e ao imperialismo.

Gráfico 3. Domínio das Relações Exteriores (Imagem do país no cenário internacional) ${ }^{10}$

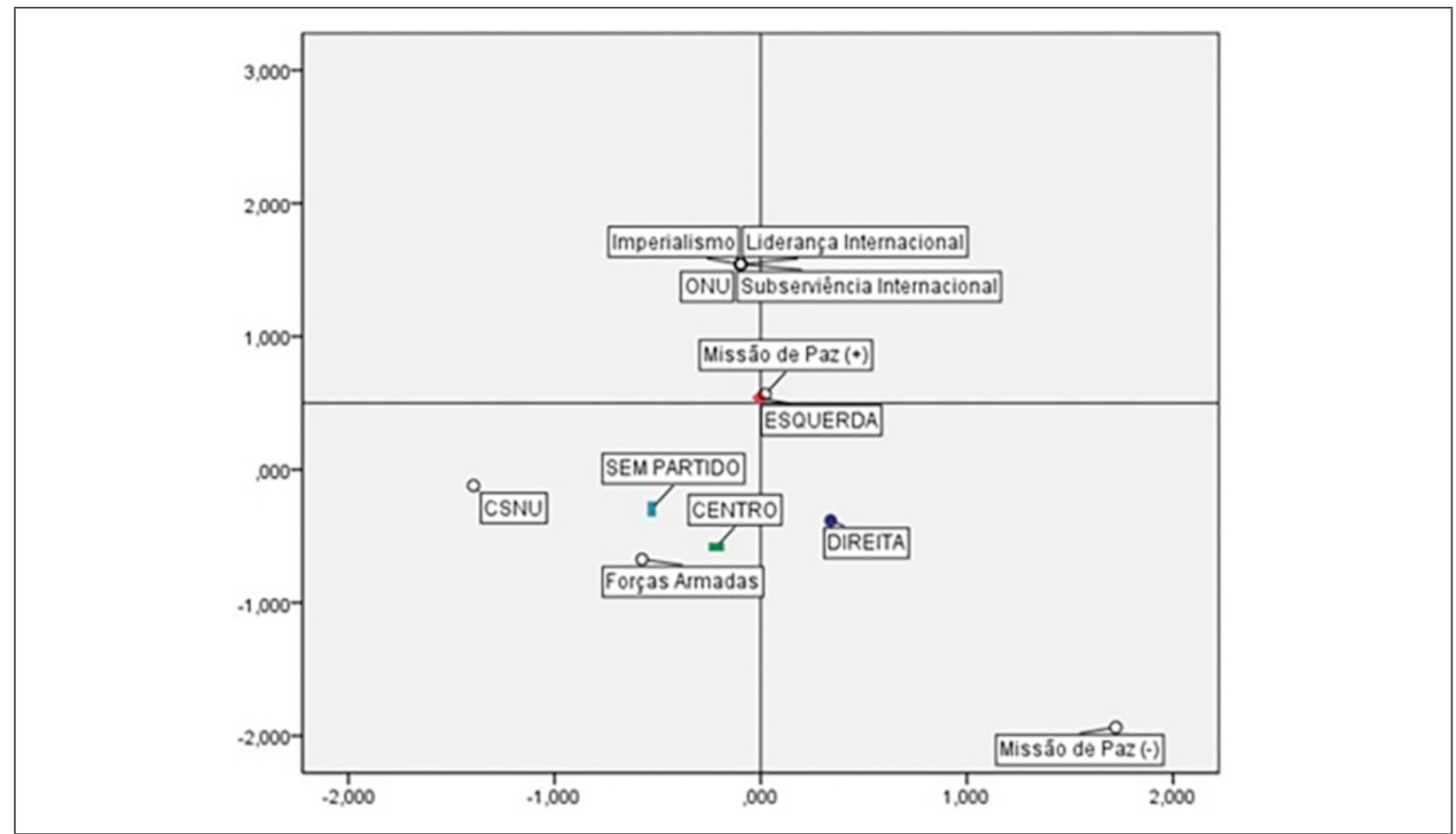

Fonte: banco de dados próprio a partir dos discursos e pareceres dos congressistas elaborado em 2015.

10 A análise de correspondência é uma técnica exploratória criada para examinar tabelas de contingência de dupla e múltipla entradas, por meio de algumas medidas de correspondência entre linhas e colunas. Os outputs fornecidos possibilitam entender a estrutura de relações entre as variáveis categóricas das tabelas. As tabelas mais comuns são as de frequências de dupla entrada, onde se tem um caso de análise de correspondência simples. Numa análise de correspondência simples, a tabela de frequências é padronizada (BOUROCHE; SAPORTA, 1982; PEREIRA, 2004), por isso os eixos x e y passam simplesmente a serem denominados de eixo 1 e eixo 2. Por isso, nesse artigo, omitiu-se os nomes das coordenadas x e y. Lembrando também que, em alguns casos, a relação é unidimensional, como na análise da dimensão "Relações Exteriores — Paraguai”. 
No domínio das Relações Exteriores - Integração Latino-Americana Gráfico 4, é possível apreender que: os membros da direita interessam-se pelo Mercosul, principalmente no que tange aos seus interesses liberalizantes; os do centro, no ato da ratificação da entrada da Venezuela no Mercosul, temiam que o presidente Hugo Chavéz inviabilizasse a união aduaneira do bloco, daí a menção negativa a ele; e os de esquerda, mais uma vez liderados pelo governo do PT, enfatizavam que os critérios utilizados pela oposição eram ideológicos, pois Hugo Chavéz não era a Venezuela e que o ângulo de observação deveria ser o do país como um parceiro estratégico. Além disso, eles também reforçavam a ideia de independência latino-americana com o aprofundamento do processo regional.

\section{Gráfico 4. Domínios das Relações Exteriores (Integração Latino-Americana)}

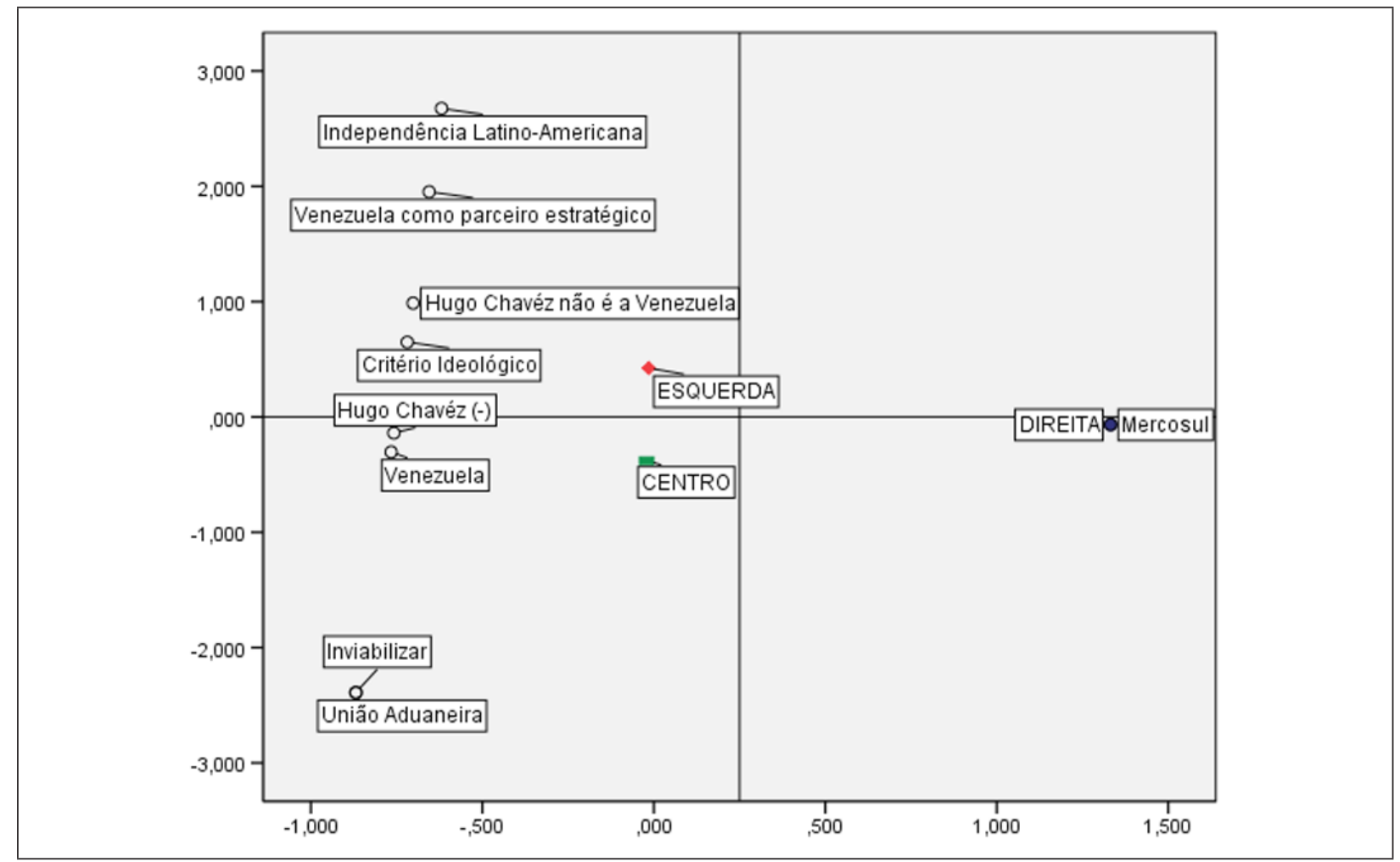

Fonte: banco de dados próprio a partir dos discursos e pareceres dos congressistas, elaborado em 2015.

No Gráfico 5, avalia-se o posicionamento dos parlamentares aos temas ligados aos Estados Unidos da América. Enquanto os partidos de esquerda, centro e direita fazem menções positivas ao país, aqueles que estavam sem partido focam nos temas da intervenção norte-americana na América Latina, bem como na pressão que os negociadores americanos exercem sobre os tomadores de decisão do Brasil. Essa constatação pode ser explicada, pois, como já foi dito, esses indivíduos que fazem parte dos "sem partido" foram aqueles que saíram ou foram expulsos do 
Partido dos Trabalhadores em 2003, e que se encontravam mais à esquerda do que a própria agremiação petista.

\section{Gráfico 5. Domínio Relações Exteriores - Estados Unidos da América}

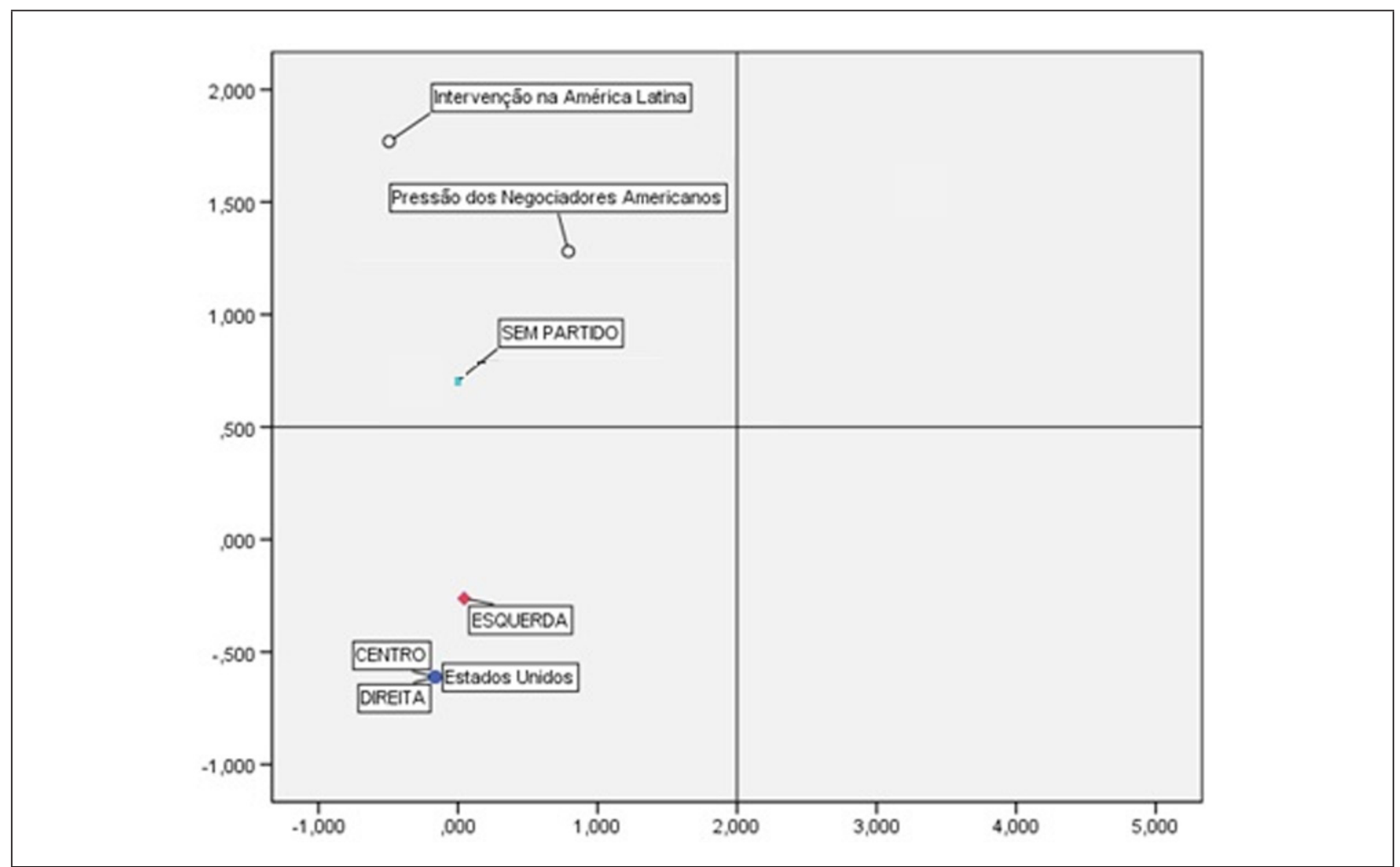

Fonte: banco de dados próprio a partir dos discursos e pareceres dos congressistas, elaborado em 2015.

No caso dos Gráficos 6 e 7, fica visível que a política externa também serve de caminho para a oposição se manifestar. Como só havia dois partidos — ambos categorizados neste trabalho como centro - resolvemos desagrupá-los da categoria ideologia e mostrá-los separadamente. No Gráfico 6, vê-se o caso que envolve a mudança da tarifa cobrada pela Usina de Itaipu. O PSDB - partido de oposição ao governo do PT - e uma ala do PMDB que, apesar de ser governista, era composto por parlamentares que faziam oposição sistemática, focam no fato de o governo ceder aos interesses paraguaios por razões ideológicas, deixando, portanto, que a tarifa cobrada por Itaipu beneficiasse o governo de Fernando Lugo em detrimento do povo brasileiro, como se vê nos discursos. Já no Gráfico 7, os mesmos partidos (PSDB e PMDB) discutem sobre a possibilidade de validação automática dos diplomas de medicina conseguidos por estudantes brasileiros em Cuba. O PSDB foca no fato de os currículos entre os cursos no Brasil e em Cuba serem diferentes e, o PMDB, na questão da indicação política dos discentes, o que resultaria em perda de qualidade dos alunos selecionados. 
Gráfico 6. Domínio Relações Exteriores - Paraguai

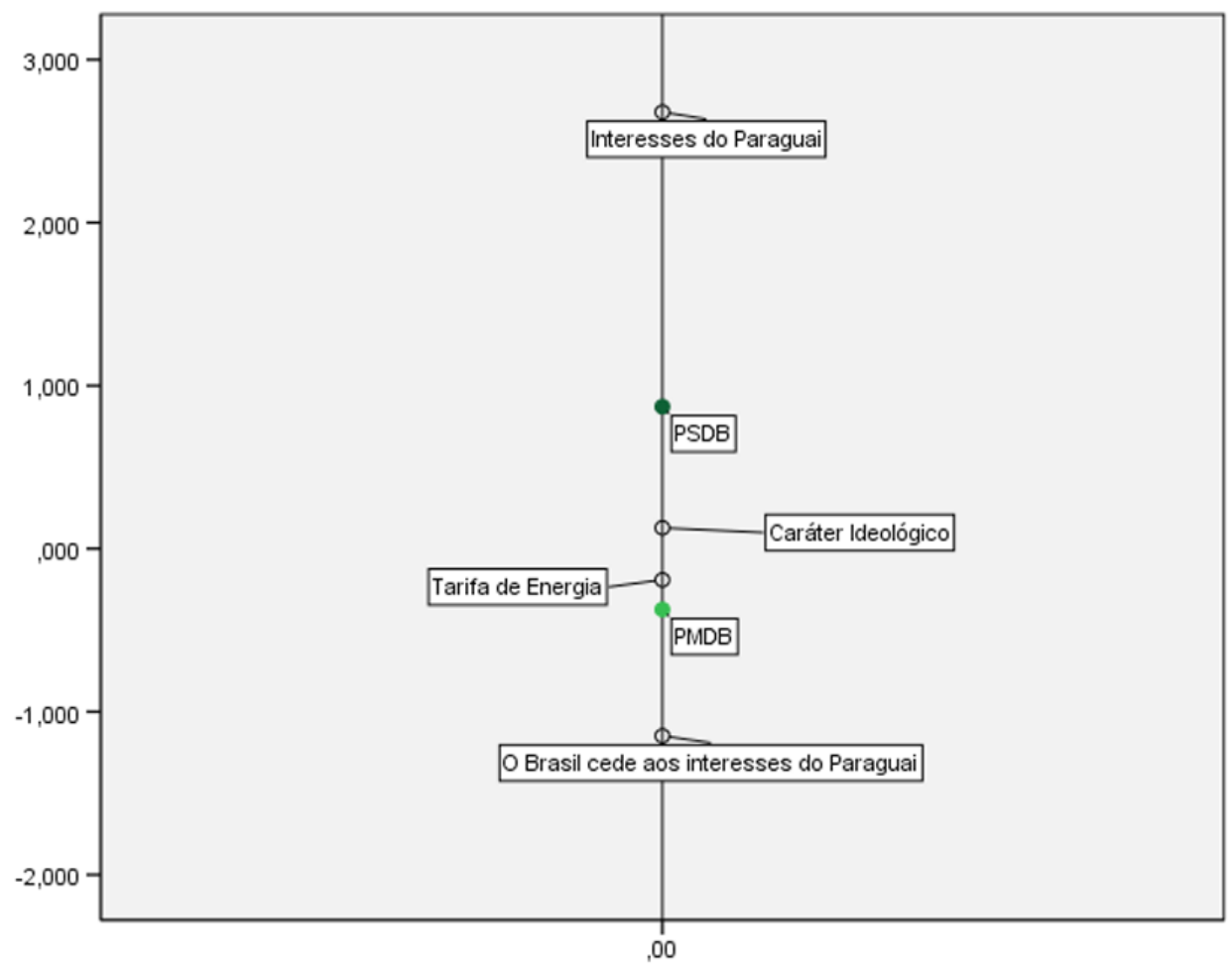

Fonte: banco de dados próprio a partir dos discursos e pareceres dos congressistas, elaborado em 2015.

Gráfico 7. Domínio das Relações Exteriores - Cuba

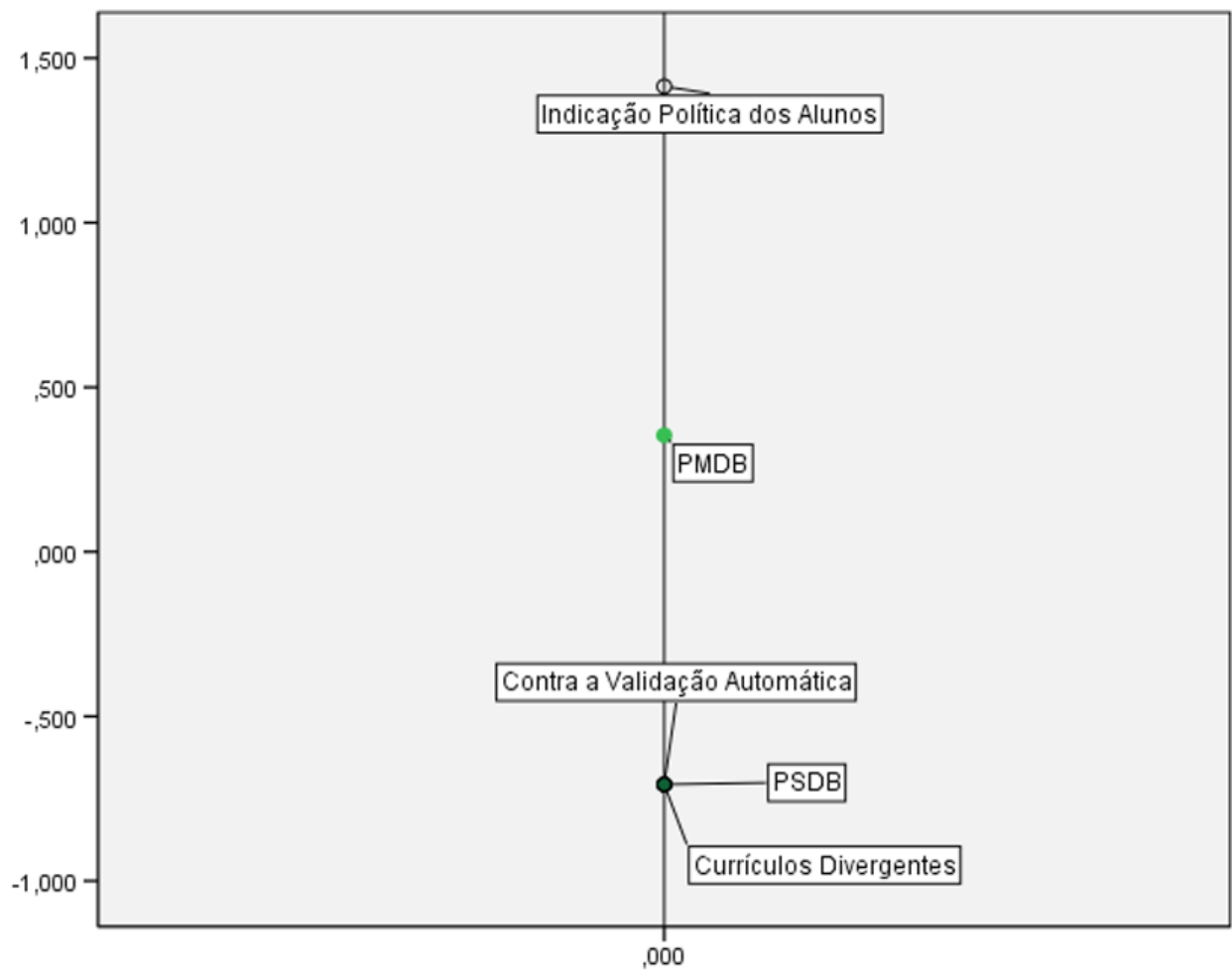

Fonte: banco de dados próprio a partir dos discursos e pareceres dos congressistas, elaborado em 2015. 
No Gráfico 8, observa-se como o posicionamento ideológico interfere sobre o que é dito pelos parlamentares. Nele, estão os resultados para a África e o Oriente Médio. No caso da direita, os parlamentares focam na relação BrasilÁfrica, no que tange aos ganhos comerciais desse vínculo; o centro, na figura do deputado Gilberto Mestrinho do PMDB/AM, diz que os negros não precisam da nossa cultura e, por isso, que a África é, claramente, atrasada; por fim, os partido de esquerda, em relação à África, apontam para os problemas enfrentados pela África do Sul durante o apartheid, exaltam a cultura africana, a partir da bancada dos deputados negros, especificamente a do PT. Já no caso do Oriente Médio, o parlamentar, que é do $\mathrm{PCdoB}$, condena o expansionismo israelense na região e propõe uma tentativa de conciliação - postura esperada, pois a crítica a Israel, por tal sigla, é bastante conhecida.

\section{Gráfico 8. Domínio dzas Relações Exteriores - África e Oriente Médio}

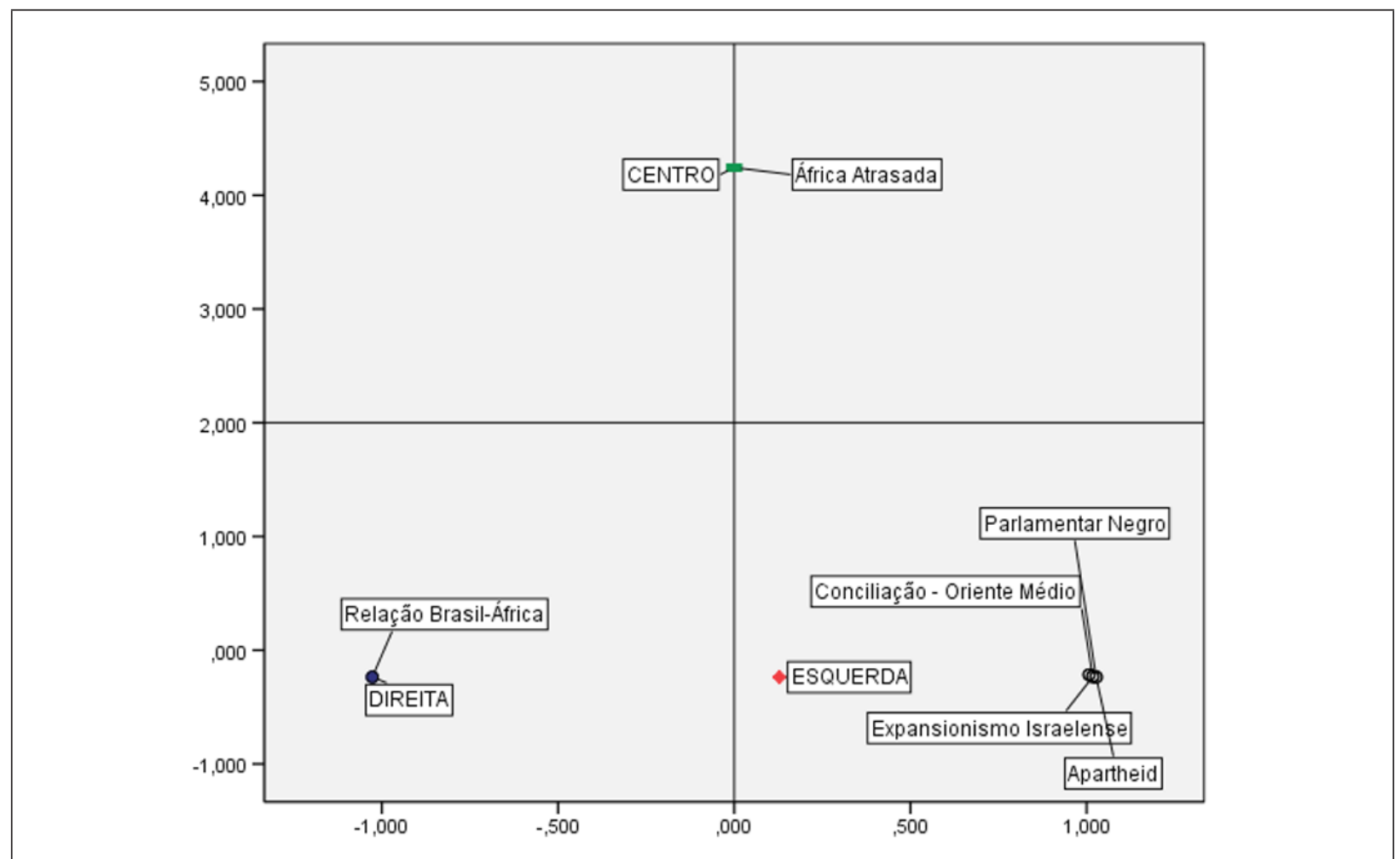

Fonte: banco de dados próprio a partir dos discursos e pareceres dos congressistas, elaborado em 2015.

No segundo domínio, o da Globalização (Gráfico 9), a direita mostra-se contrária à imigração, enquanto que os partidos de esquerda, além de se mostrarem contrários a essa postura específica da direita, também possuem um leque maior de questões em seu discurso. Para eles, a globalização é a causa dos conflitos regionais, das assimetrias econômicas no mundo e dos crimes, tal como o terrorismo. Além 
disso, acreditam que esse cenário pode ser alterado ao se incorporar na agenda a reforma dos organismos multilaterais, tornado-os, assim, mais democráticos.

\section{Gráfico 9. Domínio da Globalização}

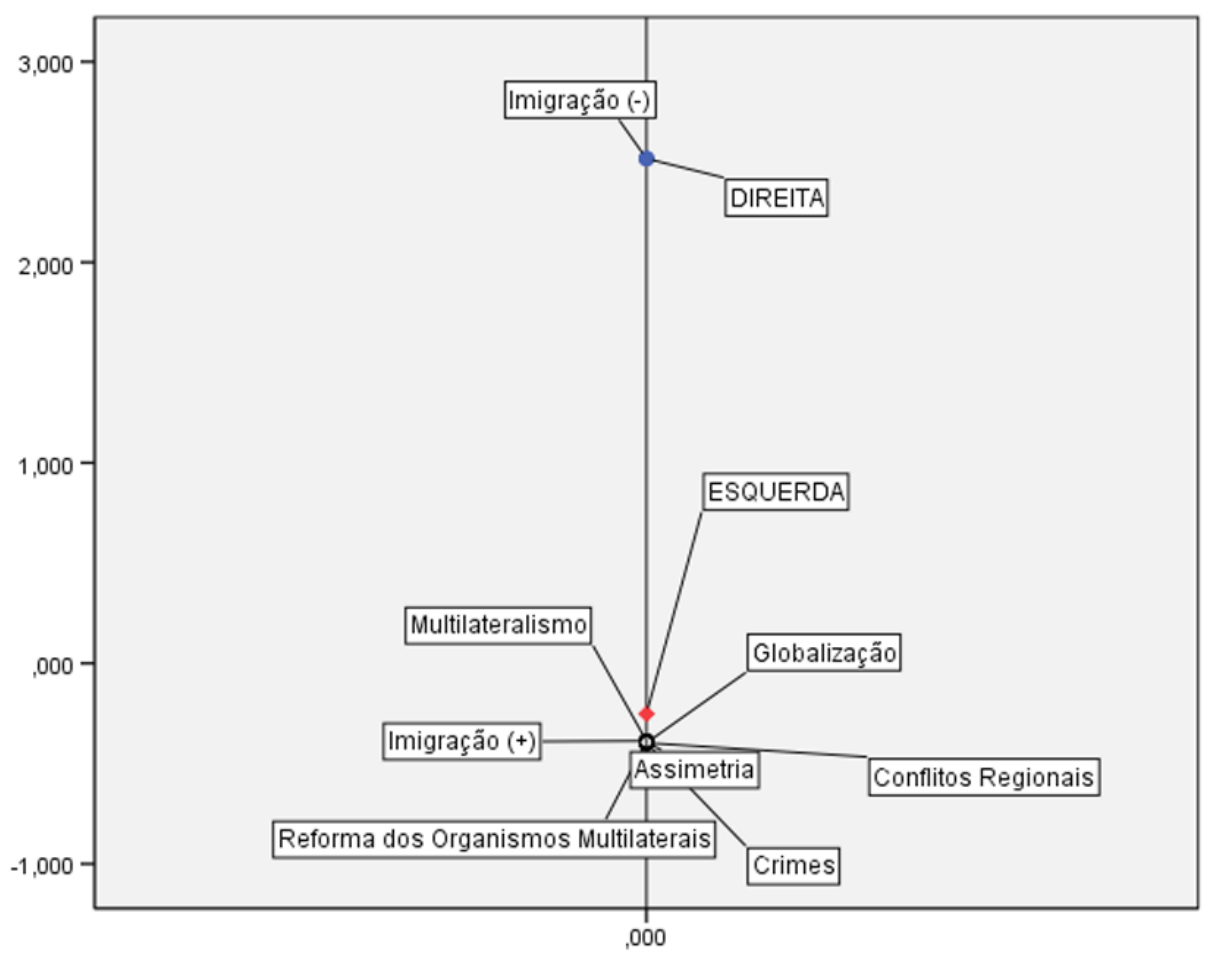

Fonte: banco de dados próprio a partir dos discursos e pareceres dos congressistas, elaborado em 2015.

No terceiro domínio, foca-se nos aspectos da Liberdade e Democracia (Gráfico 10). Tanto a direita, como o centro, quanto a esquerda atentam para os aspectos constitucionais dos atos internacionais, no intuito de saber se eles terão o respaldo da Carta Magna. Porém, há algumas diferenças importantes: a direita privilegia as questões jurídicas, tais como, os princípios da incerteza jurídica e da inconstitucionalidade; a esquerda, a busca por mais democracia e direitos humanos no sistema internacional; e, os sem partido, baseiam seus discursos focando nas iniquidades, restrições e supressões dos direitos humanos e da democracia em outras nações. 


\section{Gráfico 10. Domínio da Liberdade e Democracia}

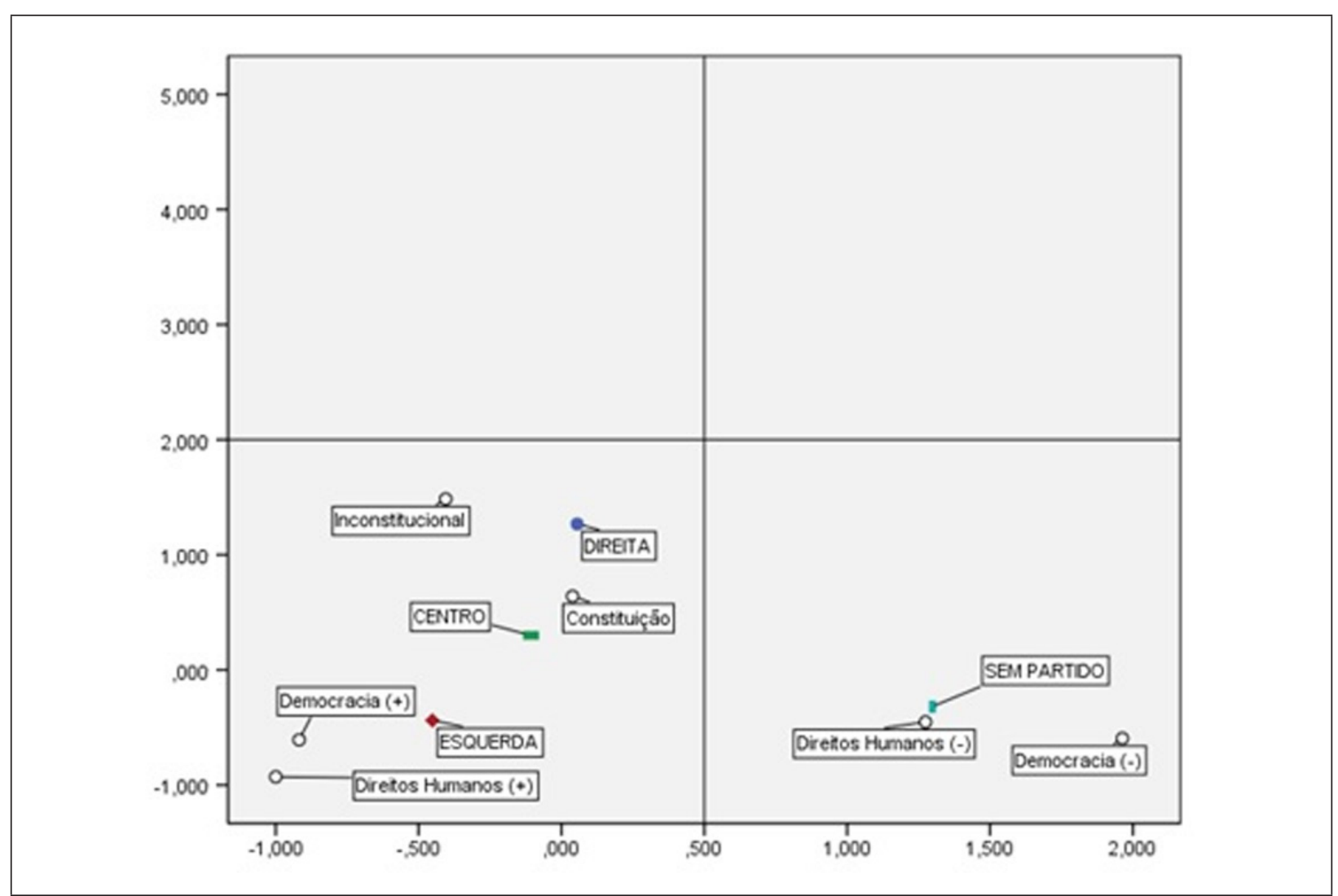

Fonte: banco de dados próprio a partir dos discursos e pareceres dos congressistas, elaborado em 2015.

No Gráfico 11, estão os resultados para a análise de correspondência para aquilo que é caracterizado como Sistema Político. Nele, fica clara a dimensão governo versus oposição. Os membros da direita fazem oposição aberta ao governo do petista Lula; os centristas, repercutem os desequilíbrios entre os poderes Executivo e Legislativo em política externa, além de fazerem menções negativas ao governo da presidente Dilma; a esquerda, por sua vez, faz oposição ao governo do ex-presidente Fernado Henrique Cardoso, referindo-se, principalmente, às privatizações ocorridas durante o seu mandato, e repercutem, positivamente, o governo do presidente Lula; por fim, os sem partido, recém saídos do PT, passam também a fazer oposição ao governo Lula. 
Gráfico 11. Domínio do Sistema Político

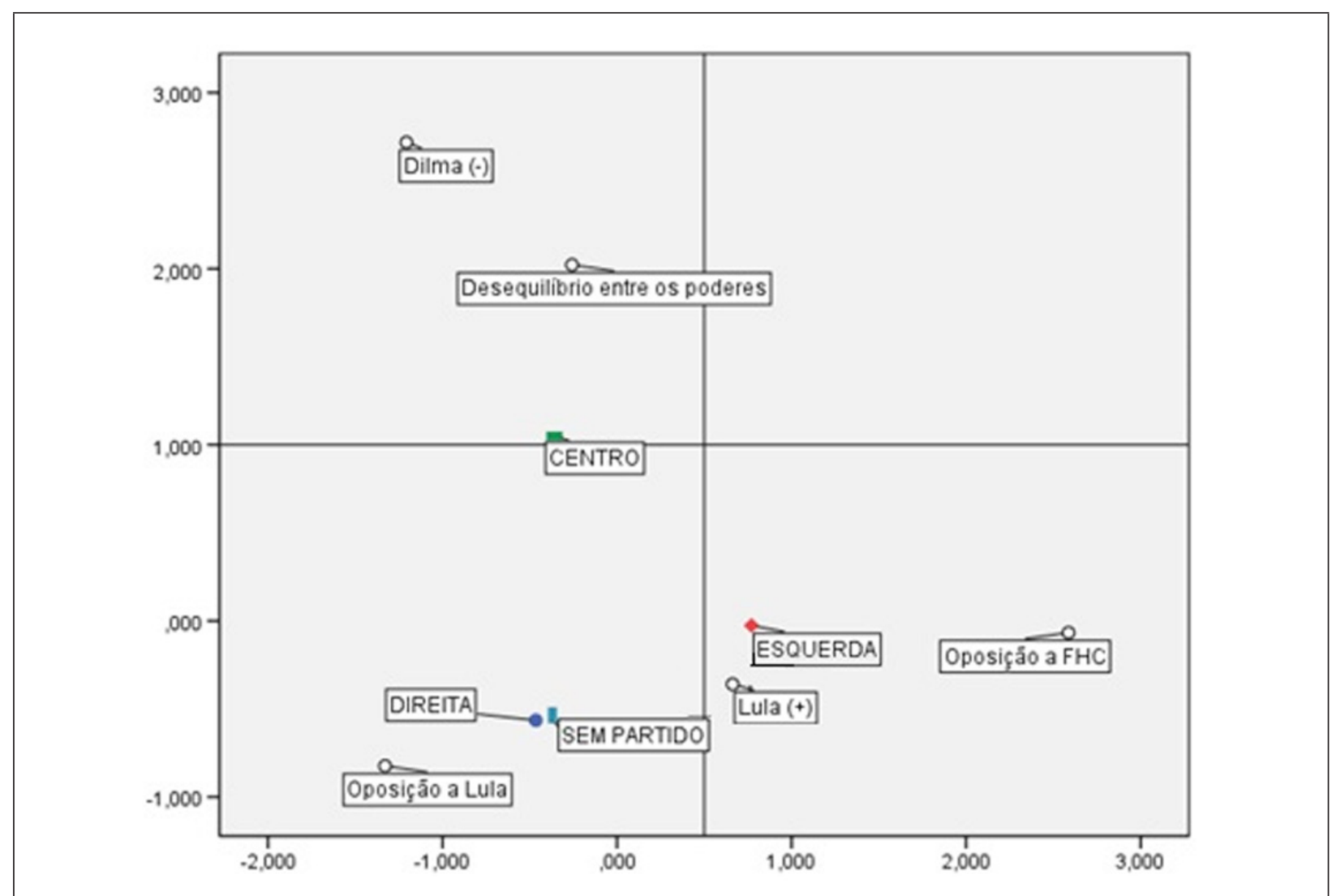

Fonte: banco de dados próprio a partir dos discursos e pareceres dos congressistas, elaborado em 2015.

Na dimensão Economia, como pode ser visto no Gráfico 12, os princípios ideológicos voltam a ser evidentes. A direita procura demarcar território buscando investimentos para os empresários nacionais, bem como se posicionando a favor das negociações da OMC na Rodada Doha, criticando a criação de novos cargos administrativos e buscando o contingenciamento das despesas públicas. Os congressistas de centro assemelham-se aos de direita, mas enfatizam, ainda com menções positivas, a economia de mercado e a livre-concorrência, e criticam o sobrecarregamento das despesas públicas. Já a agenda das esquerdas é outra. Fala-se em esquerdas porque a parlamentar sem partido, nesse caso, é Luciana Genro, que posteriormente ajudaria a fundar o PSOL. No caso dela, o discurso vai no sentido de criticar o neoliberalismo, apontando para as suas contradições. Já a outra parte da esquerda, além de tratar da livre circulação de capitais como uma condição contemporânea, não deixa de criticar o livre-comércio, principalmente aquele realizado por alguns países desenvolvidos que criam barreiras comerciais internas. Além de fazer menções negativas à especulação monetária e positivas à exportação de bens. 


\section{Gráfico 12. Domínio da Economia}

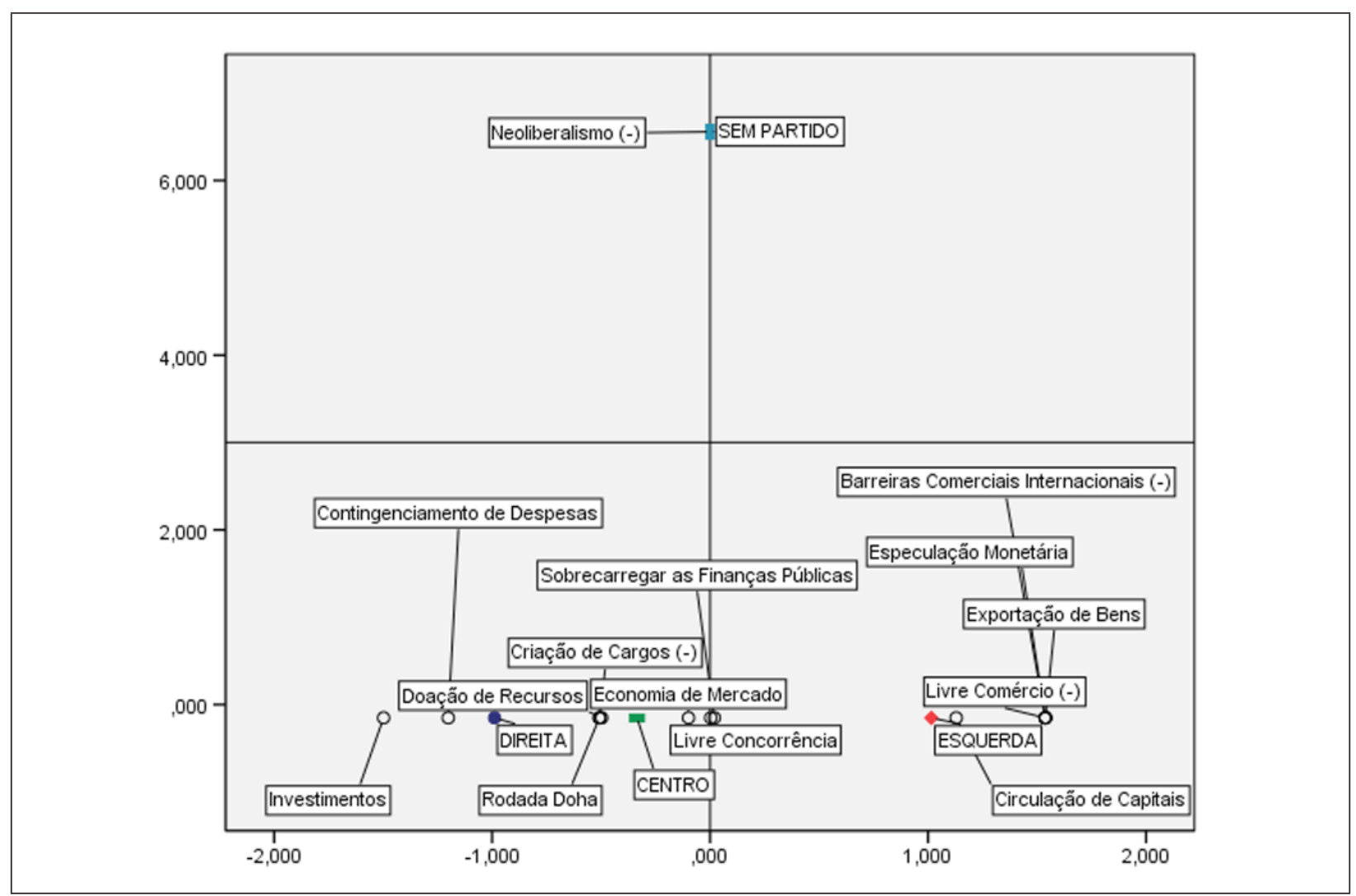

Fonte: banco de dados próprio a partir dos discursos e pareceres dos congressistas, elaborado em 2015.

Outro domínio é o do Bem-Estar e Qualidade de Vida, como pode ser visualizado no Gráfico 13. Nele, há uma disputa entre a direita e a esquerda. No material analisado, a direita passa a associar de forma negativa a pobreza a alguns espaços, como as periferias e as favelas; ao passo que a esquerda está preocupada com questões como a discriminação, o empoderamento feminino e a degradação ambiental. 


\section{Gráfico 13. Domínio do Bem-Estar e Qualidade de Vida}

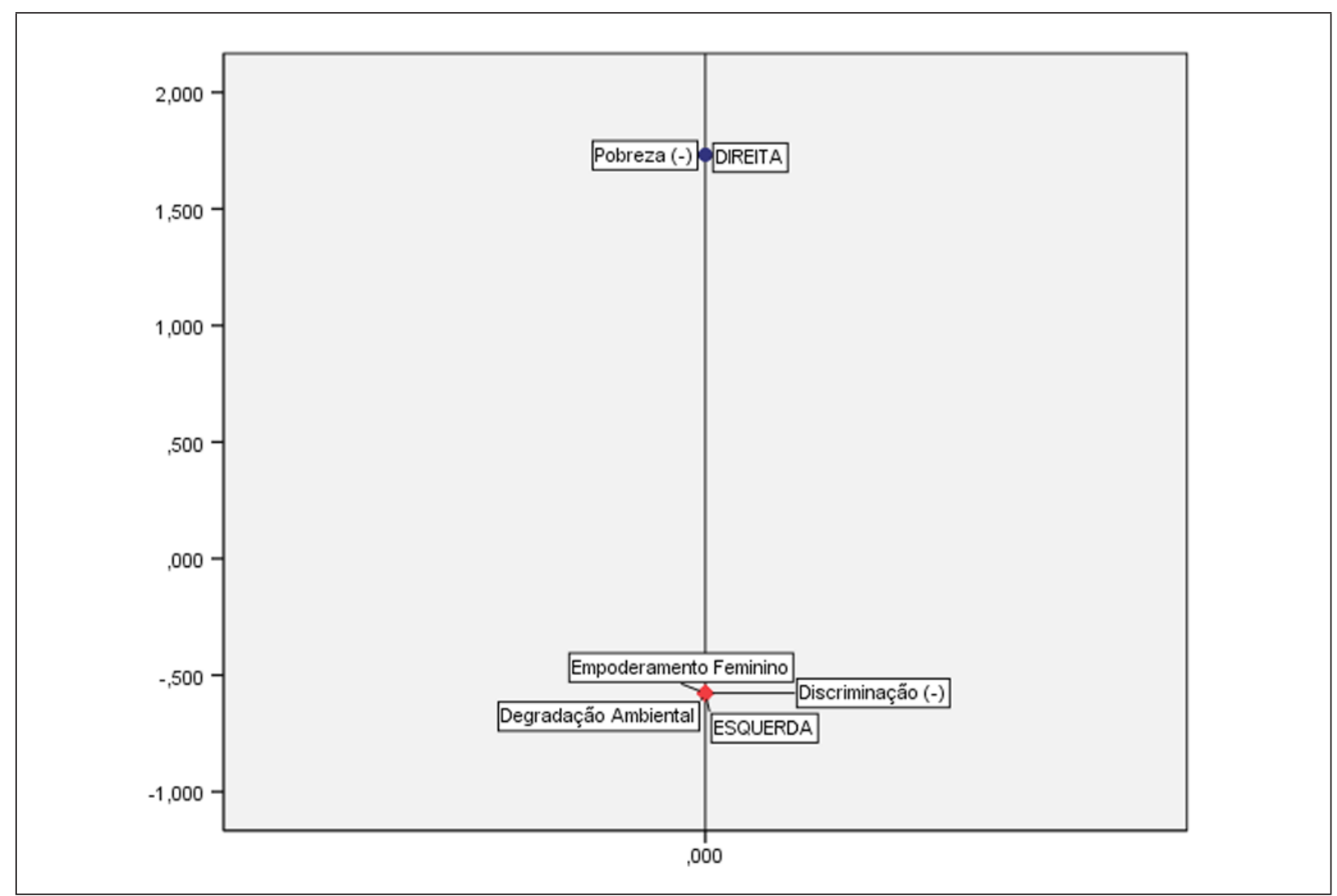

Fonte: banco de dados próprio a partir dos discursos e pareceres dos congressistas, elaborado em 2015.

Inicialmente, no Gráfico 14, percebe-se uma preocupação comum entre direita, centro e esquerda no tema das ambivalências entre as normas geradas no plano internacional e aquelas domésticas. Posteriormente, há ainda uma similaridade entre a direita e o centro no que se refere à preocupação com a segurança pública, evocando a possibilidade de utilização das Forças Armadas; já a esquerda mostrase inclinada a debater a soberania nacional entendida como, por exemplo, o não alinhamento com os Estados Unidos ou o desenvolvimento autônomo de tecnologias; já o congressista sem partido (Fernando Gabeira) refere-se ao interesse nacional como a preocupação com o deslocamento de tropas brasileiras, sem a permissão do Congresso Nacional, episódio que aconteceu durante os debates do envio de contingentes para a missão de paz no Haiti. 


\section{Gráfico 14. Domínio da Estrutura da Sociedade}

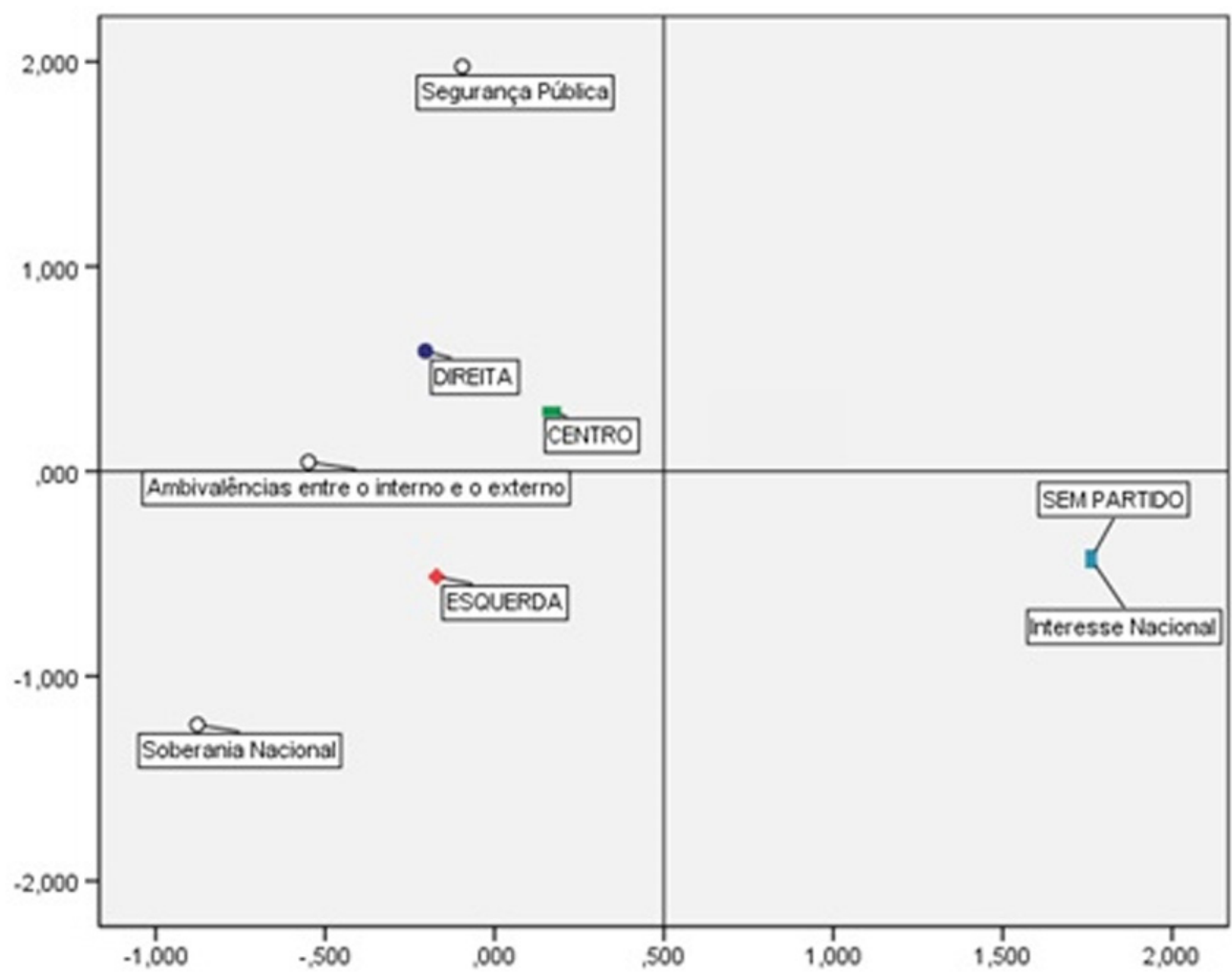

Fonte: banco de dados próprio a partir dos discursos e pareceres dos congressistas, elaborado em 2015.

A penúltima dimensão, essa não sendo original da saliency theory, é a da Questão Indígena e Segurança Amazônica. No Gráfico 15, a esquerda aproxima-se do debate sobre a Amazônia e sua segurança, o que significa soberania nacional e uma política para os povos indígenas (Estatuto do Índio e a demarcação de terras), respectivamente; o centro utiliza no seu discurso palavras negativas a se referir ao tema indígena, por exemplo, o senador Lúdio Coelho do PSDB/MS - agropecuarista/interesse federativo/Região Centro-Oeste - usa as seguintes frases: 1) "O índio está sendo tratado como um ser superior, ninguém mexe com índio"; e 2) "Estamos querendo criar nações indígenas para, amanhã ou depois, queiram intervir em nosso País em defesa de nações"; por outro lado, impressiona que a direita, que normalmente não luta pela defesa das minorias, curiosamente, faz uma série de menções positivas ao papel do índio na sociedade brasileira, como: os índios são brasileiros, respeito aos direitos indígenas, reformulação da FUNAI, demarcação de terras e que, fortalecendo as comunidades indígenas, as chances de intervenção estrangeira via Amazônia são menores. No entanto, o que explicaria esse posicionamento dos membros da direita? 


\section{Gráfico 15. Domínio da Questão Indígena e Segurança Amazônica} pela Ideologia Partidária

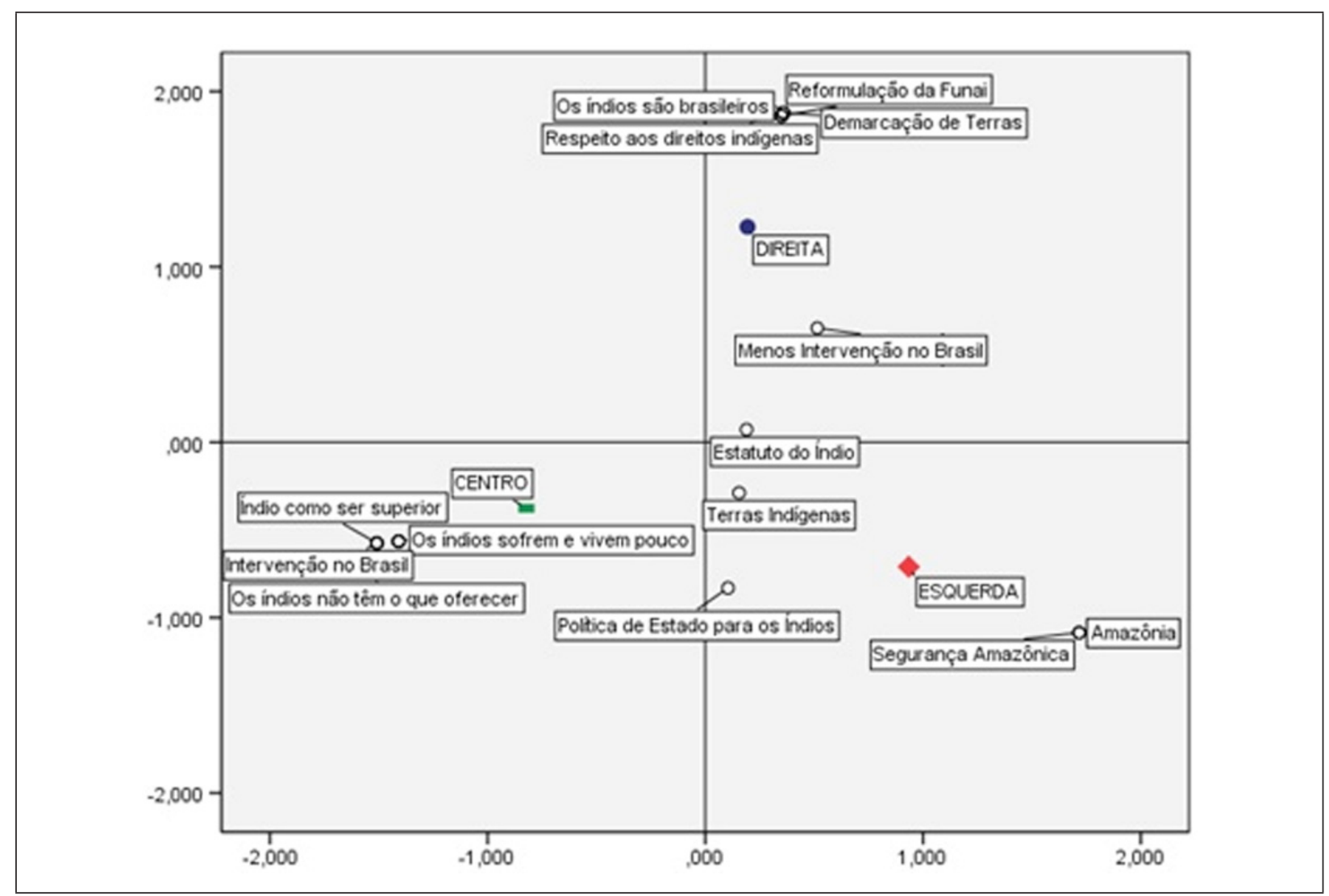

Fonte: banco de dados próprio a partir dos discursos e pareceres dos congressistas, elaborado em 2015.

A resposta para a pergunta acima encontra-se no Gráfico 16. Nele, trabalhase com as variáveis ideologia e região geográfica de forma conjunta. O resultado é que os membros da direita que se colocaram a favor da minoria indígena são oriundos dos estados da federação da região Norte, como é o caso do senador Romero Jucá, na época do PFL/RR. Ou seja, como discutido nos capítulos teóricos, o pertencimento local ou as relações com as bases de apoio nos estados também ajudam a explicar os comportamentos dos parlamentares. 


\section{Gráfico 16. Domínio da Questão Indígena e Segurança Amazônica} pela Ideologia Partidária Cruzada com a Região do Parlamentar

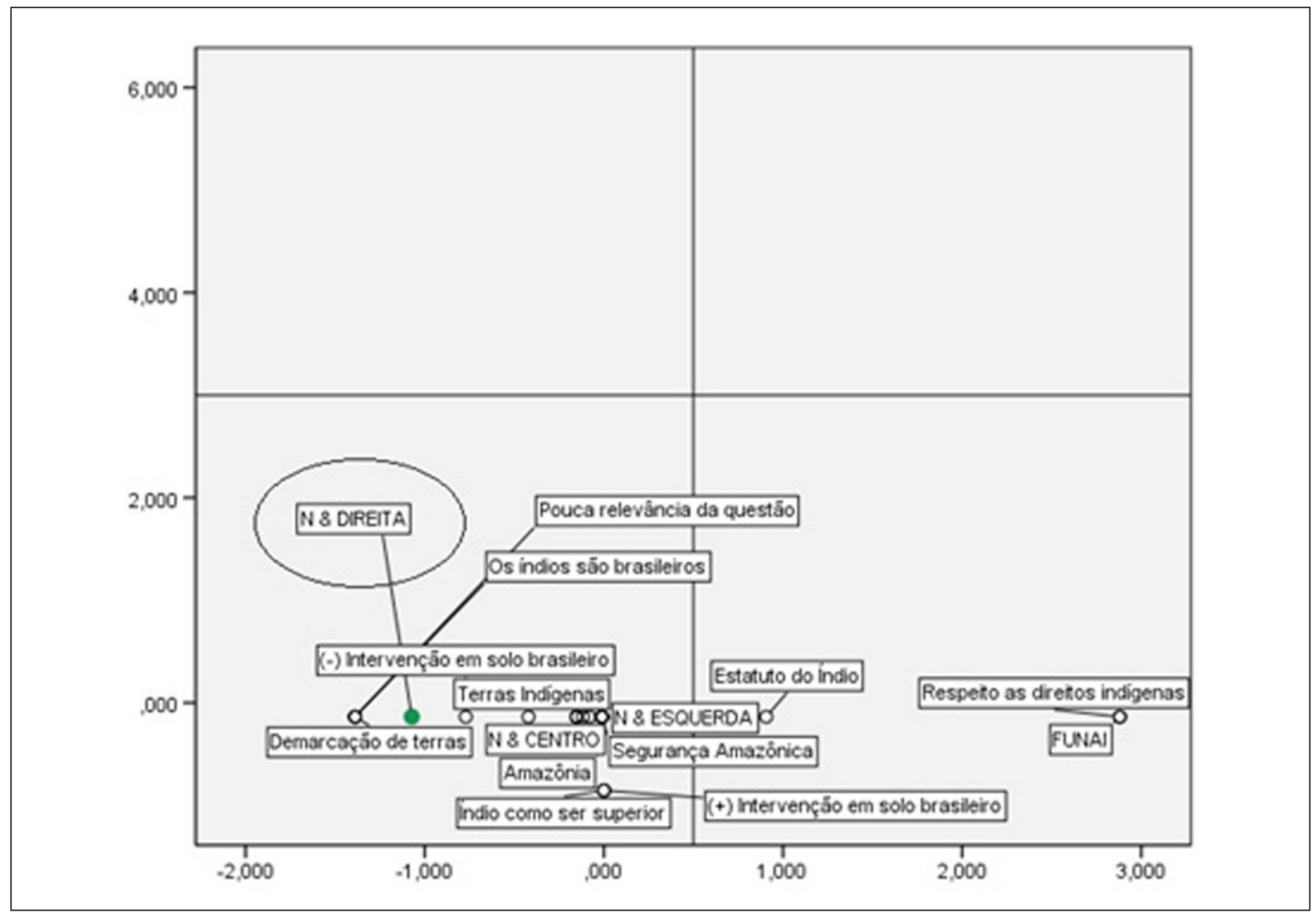

Fonte: banco de dados próprio a partir dos discursos e pareceres dos congressistas, elaborado em 2015.

Por último, tem-se a dimensão da Tramitação dos Atos Internacionais e Fiscalização do Congresso, também não presente na saliency theory. No Gráfico 17, frisa-se a preocupação de todos os parlamentares, independentemente da coloração partidária (ideológica) com as questões regimentais e a fiscalização do Congresso nos projetos relacionados à política externa. Isto é, o cuidado dos congressistas em manter suas prerrogativas constitucionais de analisar matérias dessa ordem. 


\section{Gráfico 17. Domínio da Tramitação dos Atos Internacionais e Fiscalização do Congresso}

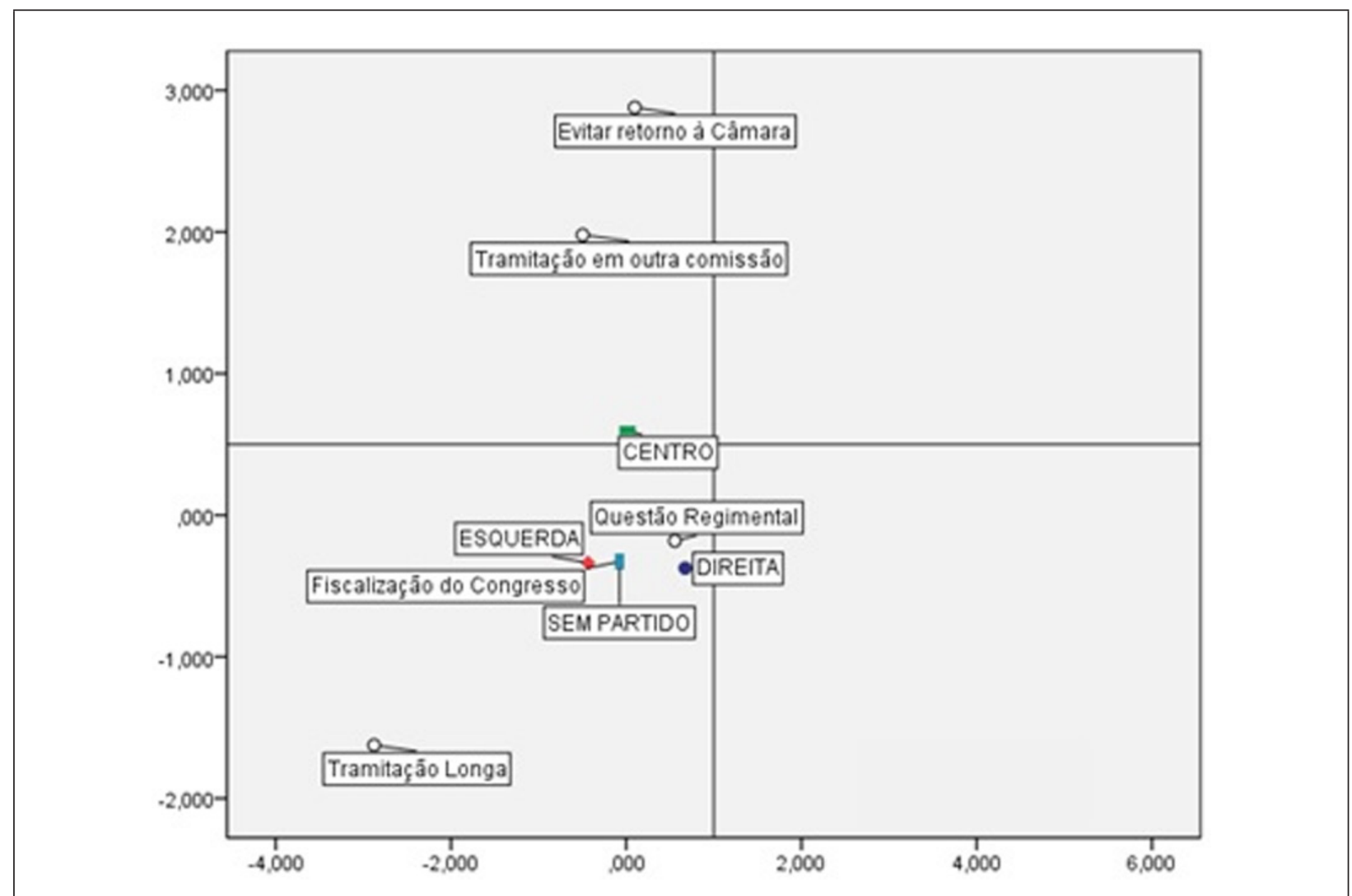

Fonte: banco de dados próprio a partir dos discursos e pareceres dos congressistas, elaborado em 2015.

\section{Considerações finais}

A partir dos achados do paper, não se pretende fazer generalizações, até porque o arsenal metodológico empregado não nos permite. O objetivo foi decifrar, por meio dos casos em que houve atuação de parlamentares, aquilo que os moviam. Para além de ser assertivo ao dizer a uma dada arena que a explicação se baseia em uma das três variáveis aqui tratadas, pleiteia-se, na verdade, a importância delas de forma geral no estudo de análise de política externa no Legislativo.

Assim, por meio das análises de correspondência, fica claro que partidos de origens ideológicas distintas adotam discursos diferentes. Ou seja, há um embate ideológico travado em matérias de política externa, resultado esperado, haja vista que foram matérias alvo de ação congressual, seja via discussão em plenário ou através da elaboração de pareceres contrários à aprovação dos projetos legislativos (ato internacional). Porém, apenas a variável ideologia não explica toda a complexidade do trabalho legislativo (como é possível perceber no 
Quadro 2) em política externa. Apesar de grande parte do embate ficar em torno dessa dimensão (esquerda-direita), a clivagem governo versus oposição e os interesses federativos acabam complementando a explanação. Com exceção do tema da fiscalização congressual dos atos internacionais, que é uma preocupação que transcende qualquer uma das questões anteriores.

Quadro 2. Síntese do debate por domínio

\begin{tabular}{|l|c|c|c|}
\hline \multicolumn{1}{|c|}{ Domínio } & Ideologia & $\begin{array}{c}\text { Governo versus } \\
\text { Oposição }\end{array}$ & $\begin{array}{c}\text { Interesses } \\
\text { Federativos }\end{array}$ \\
\hline Relações Exteriores - Imagem do país & $\mathrm{X}$ & $\mathrm{X}$ & \\
Relações Exteriores - Integração Latino-Americana & $\mathrm{X}$ & $\mathrm{X}$ & \\
Relações Exteriores - Estados Unidos & $\mathrm{X}$ & $\mathrm{X}$ & \\
Relações Exteriores - Paraguai & $\mathrm{X}$ & $\mathrm{X}$ & \\
Relações Exteriores - Cuba & $\mathrm{X}$ & & \\
Relações Exteriores - África e Oriente Médio & $\mathrm{X}$ & $\mathrm{X}$ & \\
Globalização & $\mathrm{X}$ & & \\
Liberdade e Democracia & $\mathrm{X}$ & & \\
Sistema Político & $\mathrm{X}$ & & \\
Economia & $\mathrm{X}$ & & \\
Bem-Estar e Qualidade de Vida & $\mathrm{X}$ & & \\
Estrutura da Sociedade & & & \\
Questão Indígena e Segurança Amazônica & & \\
Tramitação dos Atos Internacionais &
\end{tabular}

Fonte: elaboração do autor.

No caso da disputa governo versus oposição, conclui-se que os membros da oposição tendem a se colocar contra o governo mais para sinalizar a sua postura contrária a ele, e, por isso, votam contra uma proposta legislativa em particular. Sempre aparecem as menções contrárias a uma política específica ou a algum mandatário do Executivo (como fica bastante evidente no Gráfico 11). E, como os casos analisados são extremos, visto que provocaram tensão dentro do Parlamento, é previsível a associação entre a variável governo versus oposição e ideologia (como, por exemplo, no Gráfico 3).

Em relação à ideologia partidária, vê-se que ela é responsável por produzir demandas ético-morais a respeito da ação humana. Ou, como informa o neoinstitucionalismo sociológico, nem sempre o comportamento é guiado por cálculos estratégicos utilitários; em algumas situações, há modelos morais, cognitivos, 
identidades e protocolos prévios que são utilizados. Logo, os congressistas demonstram o position taking, isto é, o comportamento mais ideológico, na medida em que indicam seu posicionamento perante temas específicos. Nesse ponto, as discordâncias giram em torno de ideias, e não de uma proposta, matéria ou chefe do Executivo (vide o Gráfico 12, por exemplo).

Por fim, os interesses federativos também podem modificar as crenças prévias dos legisladores, bem como deixar a relação governo x oposição e a ideologia em segundo plano (Gráficos 15 e 16). Assim, a hipótese de que essas variáveis ajudam a explicar o trâmite dos atos internacionais se comprova. É claro que cada caso é singular e, logo, o peso de cada um dos elementos irá variar - por isso, o pesquisador precisa estar atento as especificidades de cada tema abordado no parlamento.

\section{Referências}

AMORIN NETO, Octavio. Gabinetes Presidenciais, Ciclos Eleitorais e Disciplina Legislativa no Brasil. Dados, vol. 43, n 3, p. 479-517, 2000.

BARDIN, Laurence. Análise de conteúdo. Lisboa: Edições 70, 2006.

BOROUCHE, Jean Marie; SAPORTA, Gilbert.. Análise de dados. Rio de Janeiro: Zahar Editores, 1982.

BUDGE, Ian et al.. Mapping policy preferences: estimates for parties, electors, and governments 1945-1998. New York: Oxford University Press, 2001.

CAMPOS, Luiz Augusto. A identificação de enquadramentos através da análise de correspondências: um modelo analítico aplicado à controvérsia das ações afirmativas raciais na imprensa. Opinião Pública, Campinas, v. 20, n. 3, p. 377-406, 2014.

CARREIRÃO, Yan. Ideologia e partidos políticos: um estudo sobre coligações em Santa Catarina. Opinião Pública (UNICAMP. Impresso), Campinas, v. 12, n. 1, p. 136-163, 2006. DOWNS, Anthony. Uma teoria econômica da democracia. São Paulo: EDUSP, 1999.

FIGUEIREDO, Argelina.; LIMONGI, Fernando. Executivo e Legislativo na nova ordem constitucional. São Paulo: Editora FGV, 1999.

FIGUEIREDO, Argelina; LIMONGI, Fernando. Instituições políticas e governabilidade: desempenho do governo e apoio legislativo na democracia brasileira. In: C. R. Melo e M. Sáez (org.), A democracia brasileira: balanço e perspectivas para o século 21. Belo Horizonte: Ed. UFMG, 2007.

GROSSMAN, Gene; HELPMAN, Elhanan. Protection for Sale. The American Economic Review, vol. 84, nº 4, p. 833-850, 1994. 
HAGER, Gregory; TALBERT, Jeffery. Look for the Party Label: Party Influences on Voting in the U.S. House. Legislative Studies Quarterly, vol. 25, n 1, p. 75-99, 2000.

HIX, Simon; NOURY, Abdul. Government-Opposition or Left-Right? The Institutional Determinants of Voting in Legislatures. Working Paper, London School of Economics, London. Disponível em: < http://personal.lse.ac.uk/hix/Working_Papers/Hix-NouryGOorLR-23March2012.pdf > . Acesso em: 24.mar.2013, 2011.

KEGLEY, Charles; WITTKOPF, Eugene. American Foreign Policy: Pattern and Process. New York: St. Martin’s Press, 1995.

KINZO, Maria D’Alva. Sistema eleitoral e partidos políticos no Brasil. In: F. KonradAdenauer (Ed.). Sistema de Governo, Legislação Partidária e Eleitoral em Países do Cone Sul. São Paulo: Fund. Konrad-Adenauer, 1993.

KLINGEMANN, Hans-Dieter; HOFFERBERT, Richard; BUDGE, Ian. Parties, policies and democracy: Theoretical lenses on public policy. Boulder: Westview Press, 1994.

KLINGEMANN, Hans-Dieter et al.. Mapping Policy Preferences II: Estimates for parties, electors and governments in Eastern Europe, European Union and OECD 1990-2003. Oxford: Oxford University Press, 2006.

LAVER, Michael; BUDGE, Ian. Party policy and government coalitions. New York: St. Martin's Press, 1992.

LEONI, Eduardo. "Ideologia, Democracia e Comportamento Parlamentar: A Câmara dos Deputados no Brasil Pós-Constituinte.” Tese de mestrado apresentada na Universidade de Brasília, Brasília, 2000.

LEONI, Eduardo. Ideologia, democracia e comportamento parlamentar: a Câmara dos Deputados (1991-1998). Dados, Rio de Janeiro, v. 45, n. 3, p. 361- 386, 2002.

MADEIRA, Rafael; TAROUCO, Gabriela. Esquerda e direita no Brasil: uma análise conceitual. Revista Pós Ciências Sociais, v. 8, p. 171-185, 2011.

MAINWARING, Scott; MENEGUELLO, Rachel; POWER, Timothy. Partidos conservadores no Brasil contemporâneo: quais säo, o que defendem, quais são suas bases. São Paulo: Paz e Terra, 2000.

MAIR, Peter. Searching for the Positions of Political Actors. In: LAVER, M. (ed.). Estimating the Policy Positions of Political Actors. New York: Routledge, 2001.

MARENCO, André. Sedimentação de lealdades partidárias no Brasil: tendências e descompassos. Rev. bras. Ci. Soc., São Paulo, v. 16, n. 45, p. 69-83, 2001.

MARENCO, André; SERNA, Miguel. Por que carreiras políticas na esquerda e na direita não são iguais? Recrutamento legislativo em Brasil, Chile e Uruguai. Revista Brasileira de Ciências Sociais (Impresso), v. 22, p. 93-113, 2007.

MARKS, Gary et. al.. Party Competition and Europeans Integration in the East and West: Different Structure, Same Causality. Comparative Political Studies, vol. 39, $\mathrm{n}^{\circ} 2$, p. 155-175, 2006. 
MCCORMICK, James; WITTKOPF, Eugene. Bipartisanship, Partisanship and Ideology in Congressional - Executive Foreign Policy Relations, 1947-1988. The Journal of Politics, vol. 52, no 4, p. 1077-1100, 1990.

MELO, Carlos Ranulfo. "Retirando as Cadeiras do Lugar: Migração Partidária na Câmara dos Deputados (1985/1998).” Tese de Doutorado, Departamento de Ciência Política - UFMG, Belo Horizonte, 1999.

MILNER, Helen; JUDKINS, Benjamin. Partisanship, Trade Policy and Globalization: Is There a Left-Right Divide on Trade Policy? International Studies Quarterly, vol. 48, p. 95-119, 2004.

OLIVEIRA, Amâncio. Partidos políticos e política externa: o comportamento legislativo na Câmara de Deputados, 1995-2009. 56 p. São Paulo: Centro de Estudos das Negociações Internacionais, USP, maio, 2013.

OLIVEIRA, Amâncio; ONUKI, Janina. Eleições, partidos políticos e política externa no Brasil. Revista Política Hoje, Recife, v. 19, nº 1, 2010.

PEREIRA, Júlio Cesar. Análise de Dados Qualitativos: Estratégias Metodológicas para as Ciências da Saúde, Humanas e Sociais. São Paulo: EDUSP, 2004.

POOLE, Keith; ROSENTHAL, Howard. Congress: A Political-Economic History of Roll Call Voting. New York: Oxford University Press, 1997.

PRZEWORSKI, Adam. A social-democracia como fenômeno histórico. Lua Nova, São Paulo, no 15 , p. 41-81, 1988.

RAY, Edward. The Determinants of Tariff and Nontariff Trade Restriction in United States. Journal of Political Economy, vol. 89, p. 105-121, 1981.

RIBEIRO, Pedro Feliú. “Comportamento legislativo e Política Externa na América Latina.” Tese de Doutorado, Departamento de Ciência Política - USP, São Paulo, 2012.

RIBEIRO, Pedro Feliú; PEREIRA NETO, Manoel; OLIVEIRA, Amâncio. Política de Comércio Exterior, Ideologia Partidária e Interesses Locais: um estudo sobre o caso chileno. Revista Cena Internacional, vol. 9, n 2, p. 33-57, 2007.

ROBERTSON, David. A theory of party competition. London: J. Wiley, 1976.

RODRIGUES, Leôncio. Partidos, ideologia e composição social: um estudo das bancadas partidárias na Câmara dos Deputados. São Paulo: EDUSP, 2002.

SANTIAGO, Rodrigo. “Os parlamentares são omissos ao debate da política externa? Um exame dos atos internacionais no Congresso Nacional”. Tese de Doutorado, Programa de Pós-graduação em Ciência Política - UFPE, Recife, 2016.

SCHONHARDT-BAILEY, Cheryl. From the Corn Laws to Free Trade. Interests, Ideas and Institutions in Historical Perspectives. Cambridge: MIT Press, 2006.

SINGER, André. Esquerda e direita no eleitorado brasileiro: a identificação ideológica nas disputas presidenciais de 1989 e 1994. São Paulo: EDUSP, 2002. 
TAROUCO, Gabriela. “Os Partidos e a Constituição: ênfases programáticas e propostas de emenda.” Tese de Doutorado, Programa de Pós-graduação em Sociologia Política — IUPERJ, Rio de Janeiro, 2007.

TAROUCO, Gabriela; MADEIRA, Rafael. Partidos, programas e o debate sobre esquerda e direita no Brasil. Revista de Sociologia e Política (UFPR. Impresso), v. 21, p. 149-165, 2013.

TAROUCO, Gabriela; MADEIRA, Rafael. Os partidos brasileiros segundo seus estudiosos: análise de um expert survey. Civitas - Revista de Ciências Sociais, v. 15, 2015.

THÉRIEN, Jean-Philippe; NOEL, Alain. Political Parties and Foreign Aid. The American Political Science Review, vol. 94, n 1, p. 151-162, 2000.

ZUCCO JR., César. Ideology or What? Legislative Behavior in Multiparty Presidential Settings. The Journal of Politics, v. 71, p. 1076-1092, 2009.

ZUCCO JR., César. Esquerda, Direita e Governo: A ideologia dos partidos políticos brasileiros. In: Power, Timothy; Zucco Jr., Cesar. (Org.). O Congresso Por Ele Mesmo. Belo Horizonte: UFMG, p. 37-60, 2011.

\section{Sites consultados:}

PHS. Programa Partidário. Disponível em: < http://phs.org.br/ > . Acesso em: dez/2015. PSOL. Programa Partidário. Disponível em: < http://www.psol50.org.br/partido/ programa/ > . Acesso em: dez/2015. 